\title{
THE VARVES AND CLIMATE OF THE GREEN RIVER EPOCH
}

\author{
By Wilmot H. Bradlex
}

\begin{abstract}
The Green River formation is a series of lake beds of middle Eocene age which occupies two large intermontane basins, one in Colorado and Utah, the other in Wyoming. The formation averages about 2,000 feet in thickness and covers an area of more than 25,000 square miles. Many of its beds of marlstone, oil shale, and fine-grained sandstone contain varves. As the origin of these varves is closely linked with the climate the writer has attempted rough quantitative estimates of several elements of the climate of the Green River epoch. These estimates are based largely upon the relative area of the lake and its drainage basin. A climate is postulated which was characterized by cool, moist winters and relatively long, warm summers. Presumably the temperature fluctuated rather widely from a mean annual temperature that was of the order of $65^{\circ} \mathrm{F}$. The rainfall varied with the seasons and probably also fluctuated rather widely from a mean annual precipitation between 30 and 43 inches.

One type of varve predominates. This consists of a pair of laminae, one of which is distinctly richer in organic matter than the other. The contacts between the two parts of the varve and between successive varves are generally sharp. The varves differ considerably in thickness according to the type of rock in which they occur and range from a minimum of 0.014 millimeter in the beds of richest oil shale to about 9.8 millimeters in the beds of fine-grained sandstone. The average thickness of the varves, weighted according to the quantity of each type of rock in the formation, is about 0.18 millimeter.

The assumption that the pairs of laminae are varves is tested, first, by analogy with the varves in the deposits of modern lakes and, second, by calculation of the thickness of annual laminae to be expected in the ancient Green River Lake based upon data of present stream loads.

The bipartite character of the varves is explained by postulating a more or less continuous sedimentation of mineral and organic constituents, with first a peak in the production of the carbonates and then a peak in the production of the plankton, both peaks apparently occurring during the summer, and by assuming that the primary difference in composition was accentuated by the differential settling rates of the two principal constituents. The preservation of the varves suggests that the lake water was thermally stratified and that the lake may not have been more than $\mathbf{7 5}$ or 100 feet deep where the varved deposits accumulated.

Three cycles of greater length than the varve cycle are suggested by fairly regular recurrent variations in the thickness of the varves and in the thickness and character of certain beds and by the fairly regular spacing of certain salt-mold layers. The first of these cycles averaged a little less than 12 years in length and appears to correspond to the cycle of sunspot numbers. The second cycle had an average length of about 21,600 years and suggests the average period of about 21,000 years which is the resultant of the cyclic changes of eccentricity of the earth's orbit and the cycle of the precession of the equinoxes.
\end{abstract}

The third cycle, which was about 50 years long, agrees with no well-established rhythm.

From measurements of the varves the Green River epoch is estimated to have lasted between $5,000,000$ and $8,000,000$ years. The rate of accumulation of the fluviatile deposits above and below the Green River formation is estimated as about 1 foot in 3,000 years, which would indicate that the combined length of the Wasatch, Bridger, and Uinta epochs was between $8,000,000$ and $25,000,000$ years. From these figures the duration of the Eocene epoch is estimated as between 13,000,000 and about $33,000,000$ years, the average of these estimates being a little less than $23,000,000$ years. This estimate agrees rather closely with estimates of the duration of the Eocene epoch based on the age determinations of radioactive minerals, but it is entirely independent of them.

\section{INTRODUCTION}

Estimates of the age of the earth and of intervals of geologic time in terms of years have long fascinated geologists. Of late the accuracy of these estimates has been materially increased by using the rate of disintegration of certain radioactive minerals. As the methods involved in these determinations come to be more and more refined the results may be relied upon with increasing confidence. Even so, independent evidence which can be used as a check will always be desirable. Annual strata or varves ${ }^{1}$ in sedimentary rocks seem most likely to yield data from which reliable check estimates can be made, but only rarely is such a record of the seasons preserved. Varves in the Pleistocene and recent glacial deposits furnish probably the best-known examples of this type of seasonal record, though varves in the glacial deposits of older geologic periods are becoming better known. Seasonal laminae in marine deposits, not related to glacial phenomena, are even more rare; nevertheless they are known, and one of the most interesting occurrences has recently been described and thoroughly discussed by Rubey. ${ }^{2}$ The recognition of varves in the

1 Ernst Antevs (Retreat of the last ice sheet in eastern Canada: Canada Dept. Mines Mem. 146, p. 1, 1925) gives the following definition and etymology of varve: "De Geer (1912, p. 253) proposed the use of the word varve, n., pl. -s, English and French-Warw, pl. -e, German-as an international term for the distinctly marked annual deposit of a sediment regardless of its origin. A varve usually consists of two but might consist of more different layers, and in the varved late glacial clay mostly of one layer of silt and one layer of stiff clay. The Swedish word oarv (old spellings hwarf and hoarf, Icelandic hwerf means turn, round, revolution (of a body), lap (sport term), time (wind a band once, four times round), row, tier, course, and layer. (Cf. the English words warve, $n$., same as wherve, $n$., meaning a whirl of a spindle, and wherve, $n$., same as whorl, $n$., meaning the fly of a spinning-wheel, etc.)"

2 Rubey, W. W., Lithologic studies of fine-grained Upper Cretaceous sedimentary rocks of the Black Hills region: U. S. Geol. Survey Prof. Paper 165-A (in press). 
Green River formation is not entirely new. Sayles ${ }^{3}$ says:

Blackwelder has recently made a study of oil shales from the Green River region. This shale has very regularly alternating brown and black bands. Black welder took the specific gravity of the material of these brown and black layers and found the former had an average specific gravity of about 1.9 and the latter about 1.3. This, in the opinion of Blackwelder and the writer, is a case which strongly suggests seasonal deposition.

White ${ }^{4}$ wrote of certain beds in the Green River formation, "The lamination of the sapropelic deposits may be seasonal or due, in many cases at least, to the generative periods of the principal organic constituent of the raw material."

The records afforded by varved rocks are chiefly valuable for measuring short intervals of geologic time, but when they can be used for estimating intervals of time long enough to be compared with estimates based on the lead-uranium ratio of radioactive minerals an unusual interest attaches to them. The lacustrine varves in the rocks of the Green River formation provide the basis for an estimate of the length of the Eocene epoch which seems to agree rather closely with current estimates based upon radioactive determinations. Accordingly it is the primary purpose of this report to describe the thin rhythmic laminæ found in certain beds of the Green River formation, to test the hypothesis that they are varves, and to interpret their significance in terms of time and in terms of the conditions that prevailed during their deposition.

Quantitative estimates of the various factors of past climates are as desirable as estimates of geologic time. Usually, however, the results of such inquiries are disappointing because the available evidence is indefinite. Certain relations between the size of one of the ancient Green River lakes and the area of its hydrographic basin appear to offer that desired definiteness which is necessary in order to attempt even a partial reconstruction of an ancient climate. For this reason and because the origin of the varves is so intimately linked with climate, the secondary aim of this report is to attempt a quantitative estimate of several factors of the climate that prevailed in the vicinity of the ancient Green River lakes during the middle of the Eocene epoch.

\section{FIELD WORK AND ACKNOWLEDGMENTS}

The field work upon which this report is based was done in the years 1922 to 1925 . In 1922 the writer assisted J. D. Sears, of the United States Geological Survey, in Moffat County, Colo., and in southern Sweetwater County, Wyo. In 1923 the

\footnotetext{
a Sayles, R. W., The dilemma of the paleoclimatologists: Am. Jour. Sci., 5th ser., vol. 3, p. 458,1922 .

t White, David, The carbonaceous sediments, in Twenhofel, W. H., Treatise on sedimentation, p. $302,1926$.
}

writer was assisted by C. H. Dane, and in 1924 by C. E. Erdmann, both also of the Geological Survey; in 1925 , by $R$. D. Ohrenschall. Most of the field data used in this report, however, were obtained in 1925 while the writer was studying the stratigraphy of the Green River formation in northwestern Colorado and northeastern Utah.

The writer wishes to express his thanks to Walter N. White, of the United States Geological Survey, who furnished the data on evaporation rates and criticized the section on the climate of the Green River epoch; to Prof. E. W. Berry, of Johns Hopkins University, who read the section on climate and offered critical suggestions; and to his colleagues of the Geological Survey, particularly W. W. Rubey and C. H. Dane, whose suggestions and criticism have been very helpful.

\section{TOPOGRAPHY AND DRAINAGE OF THE ANCIENT GREEN RIVER BASIN AND ITS VICINITY}

The Green River formation comprises a series of lake beds of middle Eocene age laid down in two large intermontane basins, one in Wyoming, the other in Utah and Colorado. The formation covers an area of more than 25,000 square miles and has an average thickness of about 2,000 feet. For the lake that occupied the Green River Basin of Wyoming during the Green River epoch the writer proposes to use the name Gosiute Lake, which King ${ }^{5}$ suggested long ago. The limits of this ancient lake as determined by subsequent studies show that instead of extending from somewhere in the vicinity of Middle Park, Colo., westward as far as longitude $116^{\circ}$, as King supposed, the lake was restricted to the Green River Basin. (See fig. 14.) South of the Uinta Mountains, in Utah and Colorado, a single large body of water occupied the Uinta and Piceance Creek Basins during the greater part of the Green River epoch, and this lake the writer proposes to designate Uinta Lake. Although it seems probable that Uinta Lake was divided into two or possibly three lakes at certain stages of low-water level there appears to be no need to name these parts.

The drainage basin of Gosiute Lake apparently included more than the Green River Basin of Wyoming; as nearly as the writer can make out, it was bounded by the Uinta and Williams Fork Mountains on the south, by the Wasatch and Wyoming Ranges on the west, by the Gros Ventre and Wind River Ranges and a partly collapsed eastward extension of the Wind River Range on the north, and by the Laramie Mountains on the east. Into this basin the Medicine Bow Range, Sierra Madre, and Elkhead Mountains projected. All these mountains were formed at the end of the Cretaceous period, and the principal modification of them since has been effected by erosion.

B King, Clarence, U. S. Geol. Expl. 40th Par. Rept., vol. 1, p. 446, 1878 
Blackwelder ${ }^{\circ}$ has shown that during the Tertiary period the mountains were first nearly buried under thick deposits; then they were modified somewhat by faulting and warping, which, in general, only accentuated the structure formed at the end of the Cretaceous period; later in Tertiary time they were exhumed by deep erosion of the early Tertiary rocks; and during in common with the general level of that part of the continent, was probably less than 1,000 feet above sea level. Presumably the great regional uplift did not occur until some time late in the Tertiary period. The assumptions which follow and from which are deduced the features. of the Eocene climate depend more or less directly upon this conception of the Eocene topog-



Fraure 14.-Outline map of the Green River Basin and vicinity, Wyoming, Utah, and Colorado, showing the present area underlain by the Green River formation, the estimated mean position of the shore line of the ancient Gosiute Lake, and the estimated boundaries of its hydrographic basin

and after this exhumation the mountain ranges themselves were more or less deeply eroded, with the result that they were considerably narrowed and their crests were lowered.

From this history it appears that the mountain ranges and high divides that form the rim of the Gosiute drainage basin were probably somewhat higher with respect to the floor of the basin during Eocene time than at present. The floor of the basin, however,

\footnotetext{
- Blackwelder, Eliot, Post-Cretaceous history of the mountains of central-western
} Wyoming: Jour. Geology, vol. 23, pp. 101-117, 193-217, 1915. raphy of the Green River Basin and the surrounding country.

The boundaries of the hydrographic basin of Gosiute Lake were, in accordance with this conception, probably almost coincident with the positions of the present mountain crests, except along the eastward extension of the Wind River Range. (See fig. 14.) These crests are, in general, high above the level of the beds of the Green River formation. At a low place in the rim in northwestern Colorado, at the east end of the Uinta Mountains, between Cross and Juniper Mountains, 
there apparently was an outlet to Gosiute Lake. This low place is only a few miles north of a thick sandy deltaic facies of the Green River formation, and as this sandy facies grades out southward into the normal very fine grained rocks that are characteristic of the formation in the Piceance Creek and Uinta Basins it suggests that a stream flowing across this low place in the rim connected Gosiute Lake with Uinta Lake, to the south, at least during certain intervals. A thick sandy facies perhaps should hardly be expected to form just below the outlet of a lake as large as Gosiute Lake, in which most of the detrital material must have settled. But the stream discharging from that lake apparently flowed for a considerable distance, perhaps 10 or 15 miles, across hogbacks of the more or less sandy Cretaceous and older rocks that form the eastward extension of the Uinta Mountain uplift. This hypothesis concerning the outlet of Gosiute Lake might be tested by a mineralogic comparison of the Cretaceous sandstone beds of that locality and of the sandstone in the deltaic facies of the Green River formation.

Most of the streams within the Gosiute hydrographic basin were apparently rather short and flowed directly into the lake, but those in the eastern part were longer and may have had considerable volume.

The mean position of the shore of Gosiute Lake is known fairly well along the west side of the Green River Basin and approximately along the south flank of the Wind River Range and the north flank of the Uinta Mountains. In other parts of the basin its position can be estimated from the position and character of the present outcrop of the Green River formation. The relations between this inferred outline of the lake and its hydrographic basin are shown in Figure 14, from which the writer calculated that the lake occupied about 36 per cent of the basin. This relation, though it varied from time to time with changes in lake level, remained approximately the same through the greater part of the Green River epoch.

\section{CLIMATE OF THE GREEN RIVER EPOCH}

Some features of the climate that prevailed in the vicinity of the ancient Green River lakes will be considered here, as they have a direct bearing on the interpretation of the lamination in the rocks of the Green River formation. The conclusions regarding the climate of Green River time have been drawn almost wholly from data on the Green River Basin of Wyoming. It is assumed that the climate in this basin, north of the Uinta Mountains, and that in the Uinta and Piceance Creek Basins, south of the Uinta Mountains, were essentially the same.

The fact that the area of Gosiute Lake remained approximately the same through the greater part of the Green River epoch in itself indicates that the climate was relatively humid or relatively cold rather than arid. Lake Bonneville ${ }^{7}$ at its maximum extent, which was during a relatively cold epoch when the rate of evaporation was not great, flooded about 38 per cent of its hydrographic basin. Three of the Great LakesSuperior, Michigan, and Huron-together occupy a little more than 36 per cent of their combined hydrographic basins.

If it is accepted that Gosiute Lake covered approximately 36 per cent of its hydrographic basin during the greater part of the Green River epoch, then the average annual rainfall of the region can be roughly approximated by using certain assumed rates of evaporation from the free water surface and from the land and plant surfaces. These assumed rates were taken from the Gulf Coast States, because of similarity between the Green River flora and the flora of those. States, and from Lakes Superior, Michigan, and Huron, because of similarity in ratio of free water surface to drainage basin.

\section{COMPARISON WITH THE GULF STATES}

The flora of the Green River formation has lately been revised by Knowlton, ${ }^{8}$ who also gives his interpretation of the ecology. Brown ${ }^{9}$ has added more than 40 new species and has also given an excellent discussion of the environment. Brown reached essentially the same conclusion as - Knowlton-that the flora had a dual aspect, many of its forms representing a warm, moist lowland type of flora and the others representing a cooler and perhaps somewhat drier upland type. As Brown's and Knowlton's conclusions are so nearly alike and as Berry ${ }^{10}$ has recently analyzed Knowlton's interpretation of the Green River flora and virtually epitomized the conclusions of both Knowlton and Brown, it will suffice to consider here only Berry's summary, which comprises also conclusions drawn from his own studies. Berry points out a striking similarity between the flora of the Green River formation and a new flora found in the so-called Bridger beds, which overlie red-banded beds of the Wind River formation in the Wind River Basin. In analyzing Knowlton's interpretation ${ }^{11}$ of the Green River flora Berry ${ }^{12}$ says:

Certainly the ensemble suggests a warm and genial climate, but that this borders on tropical in any precise use of that term or that the winter season was without frost is most doubtful. Nor is it necessary to assume that the fossils include the mechanically mixed representatives of lowland and upland associations. There is not a single well-authenticated genus

${ }^{7}$ Gilbert, G. K., Lake Bonneville: U. S. Geol. Survey Mon. 1, pp. 20, 105, 297, 1890.

8 Knowlton, F. H., Revision of the flora of the Green River formation: U. 8. Geol. Survey Prof. Paper 131, pp. 133-197, 1923.

9 Brown, R. W., Additions to the flora of the Green River formation: U. S. Geol. Survey Prof. Paper 154, pp. 279-293, 1929.

${ }_{10}$ Berry, E. W., Flora and ecology of so-called Bridger beds of Wind River Basm, Wyo.: Pan-Am. Geologist, vol. 44, pp. 357-368, 1925.

"1 Knowlton, F. H., op. cit., p. 147.

${ }^{2}$ Berry, E. W., op. cit., pp. 366-367. 
recorded from the Green River beds that is not found in the United States at the present time, and some of the genera range northward to New England and Canada.

I consider it utterly impossible to estimate the summer's heat or the winter's cold or to attempt to give mean annual temperatures, but a picture of temperature requirements can be given by citing a modern region where such a fossil flora would find optimum conditions for growth and reproduction. I have already suggested southern Louisiana as such a region, as regards temperature, rainfall, and humidity. This comparison might be somewhat extended by the statement that I know of no member of the Green River or so-called Bridger floras that would not be perfectly at home somewhere in the region between South Carolina and Louisiana in our South Atlantic and Gulf States at the present time. Hence, if general terms are imperative, these floras are warm temperate and not tropical.

The collections from the so-called Bridger beds of the Wind River Basin included some petrified wood with well-marked annual rings that clearly indicated seasonal changes, either hot and cold, or wet and dry. Although there was nothing to indicate a choice between these two alternatives Berry ${ }^{13}$ concluded from the structural details of the wood that the seasonal contrasts throughout the year were not extreme.

The analogy between the fossil flora of the Green River formation and the present flora of the South Atlantic and Gulf Coast States serves as a basis in choosing evaporation rates for the purpose of estimating the probable average annual rainfall of the Gosiute Lake Basin during the Green River epoch. Accordingly, it is assumed that Gosiute Lake occupied a region whose climate was comparable to that of Alabama to-day.

The mean annual evaporation rate from a standard Weather Bureau pan at Silver Hill, Ala., is 58.5 inches. However, W. N. White, ${ }^{14}$ of the United States Geological Survey, has found that in arid and semiarid regions these pans give too high a rate and that the observed rate has to be multiplied by a factor of 0.66. Although experimental data are lacking which would justify the application of this or any other corrective factor to readings of the standard Weather Bureau pan in humid regions, it seems likely that these pan readings are too high and that some correction should be made. In the lack of more pertinent information the factor 0.66 is used here. Probably this gives too low a rate, but if so the estimates based upon it will err in being conservative rather than extreme. The corrected mean annual rate of evaporation from the free water surface at Silver Hill, Ala., is therefore taken as 38.6 inches, or in round numbers 39 .

The mean annual rate of transpiration from plants and evaporation from the land surface in Alabama is about 37 inches. ${ }^{15}$ This figure is based upon the records of the Coosa River between Clanton and

\footnotetext{
is Borry, E. W. op. cit., pp. 360-367.

14 Oral communication.

$20 \mathrm{Mr}$. Walter $\mathrm{N}$. White, of the Geological Survey, has kindly supplied the writer with practically all the data available on evaporation rates in the United States.
}

Montgomery, Ala. According to Berry's interpretation of the flora, ${ }^{16}$ it might be legitimate to assume that this average rate of evaporation from the land and plant surfaces of Alabama is applicable to the entire land area of the ancient Green River Basin. Nevertheless the physiographic evidence seems to compel at least a rough division of the Gosiute Lake Basin into a lowland area and an upland area, and in the absence of more definite information it is assumed that the areas of the lowland and upland are equal. The mean annual evaporation rate of 37 inches will be used for the lowland. As a basis of estimate for the upland zone, which is supposed to represent the higher parts of the encircling mountain ranges, the basin of the Lenville River, in southwestern North Carolina, is chosen. The probable mean annual rate of evaporation from the land surface and transpiration from plants for the Lenville River Basin is about 30 inches. The average annual rate of evaporation and transpiration from the entire land and plant surfaces of the Green River Basin is therefore assumed to have been 33.5 inches, the arithmetical mean of the rates chosen here for the lowland and upland zones.

Now, as the land portion represented about 64 per cent of the total area of the hydrographic basin it would require 64 per cent of 33.5 inches, or 21.4 inches of precipitation over the whole basin, to balance the evaporation from the surface of the land and transpiration from plants. In the same way, as 39 inches is the assumed mean annual rate of evaporation from the free water surface, it would require 36 per cent of 39 inches, or 14 inches of precipitation over the whole basin, to balance the annual evaporation from the lake surface. A total mean annual rainfall of 35.4 , or in round numbers 35 inches, is therefore indicated if it is assumed that the lake maintained nearly its maximum dimensions but did not overflow. Salt molds widely distributed at certain levels in the rocks of the Green River formation provide a good basis for this assumption, as fairly large quantities of salt could be deposited only from a body of water which had not overflowed for a considerable period of time. Mud cracks far out in the basin indicate further that at certain stages the lake contracted greatly from its maximum extent. But there is equally good reason to believe that at other stages the ancient lake overflowed for long periods. The particular stage at which evaporation exactly balances precipitation was chosen for these computations, first, because it obviates estimates either of discharge from the lake or of rate of contraction of the lake, and second, because it is a critical stage between a saline and a fresh condition of the lake and a stage through which Gosiute Lake evidently passed repeatedly.

16 Berry, E. W., op. cit., pp. $366-367$. 


\section{COMPARISON WITH THE GREAT LAKES}

Another rough approximation, wholly independent of that based upon comparison with the Gulf States, can be reached by very indirect means through a comparison of the climatic factors in the vicinity of the Great Lakes with the same factors for the basin occupied by Gosiute Lake. Taken together, Lakes Superior, Huron, and Michigan cover a little more than 36 per cent of their combined hydrographic basins. In this respect they are comparable to the ancient Gosiute Lake, which covered about 36 per cent of its basin. But in all other respects these modern lakes differ decidedly from the ancient one. The mean annual temperature, the mean rates of evaporation from free water surfaces and from land and plants, and the mean annual precipitation are all probably much lower than those that prevailed in the region of Gosiute Lake during the Green River epoch. Moreover, although the three Great Lakes considered here occupy a large part of their drainage, they also have a large overflow. Apparently, Gosiute Lake had nothing in common with Lakes Superior, Michigan, and Huron except the ratio between free water surface and drainage area. But temperature and mean rates of evaporation are interdependent, and it might be assumed that if a reasonable figure for any one of these factors in the vicinity of Gosiute Lake during the Green River epoch can be estimated, then the others can be calculated. The assumption, however, that the temperature and evaporation rates bore the same relations to one another in the Gosiute Lake Basin during part of the Eocene epoch as they do to-day in the vicinity of the Great Lakes is plainly open to criticism. First, the two hydrographic basins which are compared are quite different topographically: one was more or less mountainous; the other is relatively flat. The topography would have a direct influence upon the air circulation over the lakes, and in a flat country the circulation and consequently the evaporation would be greater. Next, the Great Lakes lie in the path of frequent cyclonic storms, whereas Gosiute Lake presumably did not. Accordingly, the mean cloudiness is probably greater over the Great Lakes than it was over Gosiute Lake; this would tend to lower the evaporation rate but is probably offset to some extent by the greater storminess and therefore greater mean wind velocity over the Great Lakes. Finally, it seems likely from Brooks's analysis of geologic climates ${ }^{17}$ that during the Eocene epoch the precipitation was seasonal rather than uniformly distributed through the year, as it now is within the north temperate cyclonic storm belt. This also would favor evaporation. Taken in the aggregate, therefore, the conditions postulated for the region of Gosiute Lake seem to

\footnotetext{
${ }^{17}$ Brooks, C. E. P., Climate through the ages, p. 63, New York, R. V. Coleman,
}

indicate evaporation rates somewhat higher with respect to temperature than those that now prevail over the Great Lakes. Consequently an estimate of the mean annual precipitation necessary to balance the total evaporation from Gosiute Lake and its drainage basin in the Green River epoch based upon comparison with the present conditions in the region of the Great Lakes seems likely to err in being too low rather than too high.

Although temperature and evaporation are closely related, obviously other factors, particularly wind velocity and relative humidity, affect this relationship. Freeman ${ }^{18}$ has constructed a curve based on data from several lakes in temperate regions to show the relation between air temperature and rate of evaporation from large free water surfaces. In order to make this a useful tie between the climate of the Great Lakes and that of the ancient Green River Lake an estimate of the mean annual temperature of the Green River epoch is necessary.

A reasonable approximation of this temperature can be deduced from an estimate made by Brooks. ${ }^{19}$ In preparing this estimate Brooks made an elaborate statistical study of the effects upon climate produced by the relative distribution of land and sea, the altitude of the land, the direction and strength of ocean currents, and the relative amount of volcanic activity. From these studies he arrived at a mean annual temperature of $46.5^{\circ} \mathrm{F}$. during Eocene time for that part of the earth north of latitude $40^{\circ}$ north-that is, if a uniform temperature gradient is assumed, the mean annual temperature for the parallel of latitude that falls midway between $40^{\circ}$ and $90^{\circ}$, namely $65^{\circ}$ north latitude, was about $46.5^{\circ} \mathrm{F}$. This is, of course, only an estimate, but he regarded it as of the proper order of magnitude. Brooks ${ }^{20}$ also estimated the probable temperature gradient over open oceans in winter from $50^{\circ}$ north latitude to the pole during the so-called nonglacial periods as about $0.9^{\circ} \mathrm{F}$. for each degree of latitude. The temperature gradient over open oceans in the summer from $40^{\circ}$ to $70^{\circ}$ north latitude he estimated $^{21}$ as about $0.7^{\circ} \mathrm{F}$. for each degree of latitude. Then as the mean annual temperature for a point in any given latitude is very nearly. the same whether that point is located in the middle of an ocean or in the interior of a continent, it may be justifiable to assume that the mean of Brooks's winter and summer gradients $\left(0.8^{\circ} \mathrm{F}\right.$ :) calculated for conditions over open oceans during the nonglacial periods will serve as a reasonable approximation to the mean annual temperature gradient for the region of Gosiute Lake Basin during the Eocene epoch. Using this gradient and Brooks's cal-

${ }_{18}$ Freeman, J.R., Regulation of the Great Lakes-a report to the Chicago Sanitary District, p. 109, 1926.

${ }^{19}$ Brooks, C. E. P.., op. cit., p. 233.

${ }^{20}$ Idem, p. 45.

"Idem, p. 42. 
culated mcan annual temperature of $46.5^{\circ} \mathrm{F}$. for the Eocene epoch for that part of the earth between latitude $40^{\circ}$ north and the pole ${ }^{22}$ gives the mean annual Eocene temperature at $40^{\circ}$ north latitude, the latitude of the Gosiute Lake Basin, as about $66.5^{\circ} \mathrm{F}$. In view of the fact that the flora of the Green River formation indicates a climate comparable to that now found in the Gulf Const States, it is interesting to note that the present mean annual temperature along the Gulf coast is abont $70^{\circ} \mathrm{F}$.

According to Freeman's curve ${ }^{23}$ showing the relation between air temperature and rate of evaporation from a free water surface this temperature, $66.5^{\circ}$ $F$., indicates an average annual rate of evaporation of about 54 inches from the free water surface of Gosiute Lake. Howurcr, actual evaporation rates according to Freeman's computations ${ }^{24}$ are about 13 per cent lower than those indicated by this curve. Applying this correction, which seems to be justifiable, makes the mean annual rate of evaporation from the free water surface about 7 inches less, or about 47 inches. An assumption that the ratio between the mean annual rate of evaporation from a free water surface and the mean annual rate of evaporation and transpiration from land and plants was the same in the vicinity of Gosiute Lake as it is to-day in the vicinity of the Great Lakes probably introduces no great error, as the two processes are closely allied and, being contemporaneous, are con-

12 Brooks, C. E. P., op. cit., p. 233

${ }^{23}$ Frooman, J. 13., op. cit., p. 109.

24 Idom, p. 142. trolled by the same conditions. Then, as calculated by a simple proportion, the mean annual rate of evaporation and transpiration from land and plants of the Gosiute Lake Basin is 32.4 inches, or approximately 32.5 inches. As the land portion represented about 64 per cent of the total area of the hydrographic basin it would require 64 per cent of 32.5 inches, or about 21 inches of precipitation over the whole basin, to balance the evaporation from the land and plants. In the same way it would require 36 per cent of 47 inches, the rate of evaporation from a free water surface, or about 17 inches of precipitation over the whole basin, to balance the evaporation from the lake surface. A total mean annual rainfall of about 38 inches is therefore indicated by this method of calculation.

A comparison of Lakes Superior, Michigan, and Huron with Gosiute Lake is shown in the table below. The data on the Great Lakes are taken from a report by Freeman, ${ }^{25}$ except the figure for the mean annual rate of evaporation and transpiration from land and plants, which is a mean between Freeman's estimate ${ }^{26}$ for the three lakes and that of Horton and Grunsky ${ }^{27}$ for Lakes Michigan and Huron. Horton and Grunsky give no data on Lake Superior from which this factor can be derived. The other estimates taken from Freeman's report correspond with those of Horton and Grunsky.

2s Freeman, J. R., Regulation of the Great Lakes $\rightarrow$ a report to the Chicago Sanitary District, 1926.

${ }^{26}$ Idem, p. 145.

${ }^{27}$ Horton, R. E., and Grunsky, C. E., Hydrology of the Great Lakes: Report of the Engineering Board of Reviews of the Sanitary District of Chicago on the lake-lowering controversy and a program of remedial measures, pp. 15, 231, 1927.

Comparison of Lakes Superior, Michigan, and Huron with Gosiute Lake

\begin{tabular}{|c|c|c|c|c|c|c|c|c|}
\hline & Drainage area & $\begin{array}{c}\text { Area of } \\
\text { water } \\
\text { surface }\end{array}$ & $\begin{array}{c}\text { Water sur- } \\
\text { face in } \\
\text { hydro- } \\
\text { graphic } \\
\text { basin }\end{array}$ & $\begin{array}{c}\text { Mean } \\
\text { annual } \\
\text { precipi- } \\
\text { tation }\end{array}$ & $\begin{array}{c}\text { Mean } \\
\text { annual } \\
\text { temper- } \\
\text { ature }\end{array}$ & $\begin{array}{c}\text { Mean } \\
\text { annual } \\
\text { evapora- } \\
\text { tion from } \\
\text { free water } \\
\text { surface }\end{array}$ & $\begin{array}{c}\text { Mean } \\
\text { annual } \\
\text { evapora- } \\
\text { tion from } \\
\text { land and } \\
\text { plants }\end{array}$ & $\begin{array}{l}\text { Ratio of } \\
\text { mean an- } \\
\text { nual pre- } \\
\text { cipitation } \\
\text { to total } \\
\text { mean an- } \\
\text { nual evap- } \\
\text { oration }\end{array}$ \\
\hline Lakes Superior, Michigan, and Huron & $\begin{array}{c}\text { Square miles } \\
145,120\end{array}$ & $\begin{array}{l}\text { Square miles } \\
77,220\end{array}$ & $\begin{array}{r}\text { Per cent } \\
\quad 36.4\end{array}$ & $\begin{array}{l}\text { Inches } \\
29.5\end{array}$ & $\stackrel{\circ}{*} .7$ & $\begin{array}{l}\text { Inches } \\
25.2\end{array}$ & $\begin{array}{l}\text { Inches } \\
17.2\end{array}$ & 1. 47 \\
\hline Gosiute Lake & 21,900 & 12,300 & 36 & $\left\{\begin{array}{l}a 35 \\
{ }^{a} 38\end{array}\right.$ & ${ }^{b} 66.5$ & $\left\{\begin{array}{l}c 39 \\
; 47\end{array}\right.$ & $\begin{array}{l}d 35.5 \\
{ }^{\circ} 32.5\end{array}$ & $\begin{array}{l}\text { 1. } 00 \\
1.00\end{array}$ \\
\hline
\end{tabular}

- Calculated on the basis of comparison with Alabama

- Calculated from data by Brooks on the climate of the Eocene.

- Estimated from data obtained at Silver Hill, Ala.

\section{SUMMARY OF CLIMATIC FEATURES}

The annual rainfall over the basin of Gosiute Lake as indicated by a comparison with Lakes Superior, Huron, and Michigan is 3 inches greater than that indicated by comparison with the Gulf States. Nevertheless, as the two results are based on data that are wholly independent, save for the relation between water surface and land area in the two basins, they seem to indicate the probable order of magnitude of the precipitation necessary to balance evaporation$614 \tilde{5} 5^{\circ}-30-7$ d Estimated from data on Coosa River, Ala., and Lenville River, N. C.
Calculated on the basis of comparison with the Great Lakes. $\checkmark$ Estimated from Freeman's air temperature-evaporation rate curve.

namely, 35 and 38 inches, or to be safe let us say between 30 and 43 inches. It is interesting to note that an average rainfall of about 45 inches would be necessary to balance the total evaporation to-day in the region included in Georgia, Alabama, Mississippi, nnd Louisiana.

Livingston and Shreve ${ }^{28}$ have found that the most significant single expression of climatic conditions

${ }^{28}$ Livingston, B. E., and Shreve, F., The distribution of vegetation in the United States, as related to climatic conditions: Carnegie Inst. Washington Pub. 284, pp. $389-519,1921$. 
governing the distribution of types of vegetation in the United States is the ratio between the precipitation and evaporation of the period extending from 30 days before the beginning of the frostless season to 30 days after the end of the frostless season. They call this ratio the moisture ratio. The calculated data on the climate of the Green River epoch provide no means of estimating this ratio, but the ratio between the total mean annual precipitation and the total mean annual evaporation, which is numerically nearly the same, is given in the last column of the table on page 93 . These ratios must obviously be 1.0 , as the mean annual precipitation of the Gosiute Lake Basin is calculated by assuming that the total evaporation balances the total precipitation. Livingston and Shreve ${ }^{29}$ indicate an average ratio of about 1.0 for the general region of the Gulf Coast States. The ratio computed here for the region of Lakes Superior, Huron, and Michigan also agrees fairly well with the ratios given for that general region by Livingston and Shreve, who used data independent of those used by the writer. The ratios indicated by Livingston and Shreve range from a little less than 1.20 to a little more than 1.40; the ratio obtained by the writer is 1.47 .

Brooks ${ }^{30}$ gives some general conclusions regarding the probable climate and weather of the nonglacial periods that not only help to evaluate some of the assumptions used here but also add considerably to the general picture of the conditions that probably existed in southern Wyoming during the Eocene time. According to Brooks there is a critical polar temperature below which a polar ice cap forms and expands rapidly to a maximum size and above which the circumpolar oceans, if relatively free of land, remain continuously open. The great cooling effect of floating ice accounts for the rapid growth of ice caps and their stability. Once established they produce a system of cold winds that flow outward from the poles and meet opposing warm winds from equatorial regions in a zone called the polar front, which is marked by a belt of cyclonic storms. On the contrary, when the polar ocean is free from ice the warm equatorial winds, if not obstructed by land, flow far up into the polar regions and tend to effect a uniform distribution of temperature. Accordingly, there have been only two predominant types of climate during geologic time, one cool and with relatively large polar ice caps, the other warm and without ice caps. These types are stable and differ greatly in their relative distribution of temperature, storminess, wind systems, and ocean currents. The transitional type of climate in which a small ice cap forms in winter and breaks up in summer is unstable and requires temperature adjustments so delicate that it must have been rare and have existed only for brief periods.

${ }^{20}$ Livingston, B. E., and Shreve, F., op. cit., pl. 60, p. 336.

30 Brooks, C. E. P., op. cit., pp. 29-251.
Brooks ${ }^{31}$ also discusses in detail the distribution of the pressure belts and of the ocean currents and how these must change as various geographic and climatic factors change. It will suffice here merely to state his generalization that during the nonglacial periods the polar front with its zone of storminess retreats to high latitudes and the other climatic zones spread out into broader belts and so extend into higher latitudes than they now occupy. Thus the subtropical belt of high pressure moves somewhat northward, bringing generally mild weather with infrequent and erratic storms. According to this interpretation the Gosiute Lake Basin during the Eocene epoch should have had "a small rainfall during the mild winter and a long dry hot summer." 32 But as there were mountains in that region which rose several thousand feet above the general level of the continent it seems probable that the precipitation was somewhat greater there than in the adjacent regions of less relief and that in general the effect of the northward spreading of the climatic zones was less marked. Furthermore, as the region was remote from the ameliorating influences of the ocean, the seasonal extremes were probably accentuated.

Berry ${ }^{33}$ has recently discussed rather fully the climate of the Wilcox epoch (lower Eocene) in the Mississippi embayment. For his use in this discussion Brooks calculated, for two localities, the probable differences between the present mean January and July temperatures and those that prevailed during the Wilcox epoch. According to these figures Berry computed the mean January temperature of the station on the east shore of the Wilcox embayment as about $53^{\circ} \mathrm{F}$. and the mean July temperature as about $76^{\circ} \mathrm{F}$. For the station on the west shore of the embayment he gives $45.5^{\circ}$ to $49^{\circ} \mathrm{F}$. for the January mean and $82^{\circ}$ to $83^{\circ} \mathrm{F}$. for the July mean. The average annual temperature indicated by the calculated temperatures at these two stations is about $65^{\circ} \mathrm{F}$. Berry says that Brooks emphasized the fact that his formula was developed primarily for the study of glacial and postglacial climates and rests on the assumption that the general meteorologic system of the earth in Pleistocene time was similar to that of the present. And Berry remarks:

That is, of course, a doubtful assumption for Wilcox time, for we have every reason to believe that there was a diminution of the polar ice caps in the Eocene. This diminution of the polar ice caps would greatly modify the general meteorologic system and would result in much higher temperatures along the Wilcox coasts than those given above, because of the fact that the subtropical anticyclonic belts would extend poleward into temperate latitudes. *** Although the changes involved can not be stated quantitatively, their general tenor agrees admirably with the qualitative ideas regarding Wilcox climate derived from an analysis of the extensive Wilcox flora.

$\$ 1$ Brooks; C. E. P., op. cit., pp. 47-95.

${ }^{32}$ Idem, p. 63.

83 Berry, E. W., Revision of the lower Eocene Wilcox flors of the southeastern States: U. S. Geol. Survey Prof. Paper 156 (in preparation). 
An estimate of the mean annual temperature in the vicinity of the Wilcox embayment is not directly comparable with an estimate of the mean annual temperature in the basin of Gosiute Lake, for aside from discrepancy in age, which, however, is not great, the Wilcox embayment is about $6^{\circ}$ of latitude farther south than the basin of Gosiute Lake. Yet as the climatic zones of the Eocene were probably broader and less sharply defined than those of to-day the effect of this difference of latitude would be lessened.

The general correspondence of several factors indicated by these independent attempts at quantitative estimates of the climatic conditions during the Eocene epoch seems worth remarking. Hence it is perhaps reasonable to postulate a climate for the vicinity of the Gosiute Lake Basin during Eocene time which was characterized by cool, moist winters and relatively long, warm summers. Presumably the temperature fluctuated rather widely from a mean annual temperature that was of the order of $65^{\circ} \mathrm{F}$. Likewise the rainfall varied with the seasons and probably departed rather widely from a mean annual precipitation that lay somewhere between 30 and 43 inches.

\section{THE VARVED ROCKS}

Regular rhythmic laminations have been found and studied in four different varieties of rock in the Green River formation. These four varieties-organic marlstone or low-grade oil shale, moderate-grade oil shale, rich oil shale, and fine-grained limy sandstone-differ from one another chiefly in the relative proportions of constituents that are common to all. Resistant and gonerally structureless organic matter characterizes each kind of rock and predominates in the beds of riches $\imath$ oil shale. Grains of calcium and magnesium carbonate are abundant in all the rocks and are mixed in various proportions with small angular grains of quartz, orthoclase, sanidine, plagioclase, and small micaceous flakes of clay minerals.

The usual type of varve consists of a pair of laminae, one of which is distinctly richer in organic matter than the other. The contacts between the two parts of the varve and between successive varves are generally sharp and regular. (See pl. 11.) In some beds, however, especially the richer oil shales, the boundaries are irregular and less plain.

The other type of varve, which is restricted to beds of very fine-grained limy sandstone, is really a modification of the predominant type, though in size and appearance the two are rather unlike. The varves in the sandstone differ from those in the other rocks in that the mineral layers and to a less extent also the organic layers are considerably thickened by the admixture of more or less silt or very fine sand. They also differ from nearly all the varves in the other rocks in that they show a gradation in grain size from coarse at the bottom to fine at the top. Near the base the grains average about 0.02 millimeter in diameter and at the top they average between 0.004 and 0.006 milimeter. The upper, fine-grained part of these varves contains the organic matter, but the boundary between this organic part and the lower, mineral part is in most varves transitional. On the other hand, the contact between successive varvesthat is, between the fine-grained organic layer and the next mineral layer above-is invariably sharp and clearly defined. (See pl. 12, A.) The average thickness of 32 of these varves is 1.16 millimeters, but the range in thickness is great, from 0.6 to 9.8 millimeters. The structure of some of the thinnest of these varves is nearly identical with that of the predominant varve type, even to the relatively sharp separation of the organic layer from the mineral layer.

The varves in the beds of organic marlstone and oil shale, which are of the predominant type, are consistently thinner than those in the sandstone. (See pl. $12, B$.) The average thickness of 268 varves measured in four different beds of organic marlstone from localities in Colorado and Wyoming is 0.167 millimeter. The extreme range in thickness is from 0.014 to 0.37 millimeter, but the thickest varves are unusually coarse grained and the thinnest are correspondingly fine grained. In two of the marlstones the mineralrich parts of the varves are two or three times as thick as those rich in organic matter. Another marlstone, collected near the mouth of Piceance Creek, Colo., is unusual in that the organic parts of the varves average about one and one-half times as thick as the mineral parts. A fourth marlstone, which is virtually a limestone, is unusually coarse grained and shows a nearly uniform diminution of grain size upward from the base to the top of each mineral layer. At the base most of the grains are about 0.034 millimeter in diameter, but at the top the average grain size is between 0.003 and 0.005 millimeter. The parts of these varves rich in organic matter are excessively thin, and the mineral layers contain only the minutest quantities of organic matter. This distribution of organic matter is also abnormal, for most commonly the mineral layers of marlstone varves contain sufficient organic matter to give them a perceptible yellowish tint, and the organic layers contain enough mineral grains to have a distinctly granular aspect.

In both the rich and the moderately good grade of oil shale the varves are of one type and differ only in average thickness. (See pls. $13, A$ and $B ; 14, A$.) In the richest beds of oil shale, those whose yield ranges from about 35 gallons to more than 60 gallons to the ton, the organic parts of the varves generally contain a relatively small quantity of mineral matter and the mineralrich parts a relatively large quantity of organic matter. 
In the mineral-rich laminae carbonate grains and flakes of clay minerals predominate, though clastic grains of quartz and feldspar are more plentiful than in the organic laminae. The minerals most common in the organic laminne are minute anhedral and euhedral carbonate grains and clay minerals. Sanidine grains and angular splinters of quartz, glass, and plagioclase, which are presumably of volcanic origin, may be found in either part of the varve without apparent relation to its composition. The average thickness of 143 varves measured in four. different samples of very rich oil shale from a place near the head of Clear Creek, Colo., is 0.037 millimeter. The maximum range in thickness is from 0.014 to 0.153 millimeter. It is worthy of note that the average thickness is near the minimum. In these richest oil-shale beds, three of which are from the Mahogany Ledge, in sec: 9 , T. 5 S., R. 98 W., Garfield County, Colo., the organic parts of the varves equal or exceed a little in thickness the mineral-rich parts. In the bed yielding nearly 60 gallons of oil to the ton the organic laminae are themselves more or less plainly laminated. (See pl. 14, A.) The possible significance of these most minute rhythms is considered on page 102 , where the origin of the varves is discussed.

In moderately good oil shale - that is, shale yielding 15 to 35 gallons of oil to the ton-the varves range from 0.03 to 0.114 millimeter in thickness; the average thickness is 0.065 millimeter. This figure is based on the measurement of only 18 varves in a single specimen from the type locality of the Green River formation at Green River, Wyo. The varves of this specimen, however, are particularly interesting because they provide a means for measuring a larger cycle recorded in the same bed. (See pl. 14, B.) For some unknown reason easily measurable varves in oil shale of this grade are much more rare than in beds of very rich oil shale or in the much leaner beds of organic marlstone.

Laminations that may possibly be varves in rock of another type are represented by the successive regular layers of algal deposits in many of the algae reefs of the Green River formation. These average about 6 millimeters in thickness. As they have been discussed by the writer in an earlier report ${ }^{34}$ and as they are quantitatively unimportant they will not be treated again here, although they will be used in making estimates of the duration of the Green River epoch.

The above descriptions show that the varves range in thickness from 0.014 millimeter in the beds of richest oil shale to 9.8 millimeters in the fine-grained sandstone. The average thickness, weighted according to the quantity of each type of rock in the Green River formation, is about 0.18 millimeter.

s Bradley, W. H., Algae reefs and oölites of the Green Rivor formation: U. S. Geol. Survey Prof. Paper 154, pp. 203-223, 1929.

\section{PROBABLE TIME VALUE OF THE RHYTHMIC LAMINAE}

\section{ANALOGY WITH MODERN LAKE DEPOSITS}

In the preceding description of the regular, rhythmic laminations in the rocks of the Green River formation the time value of the rhythm has, for convenience of exposition, been assumed as one year, and accordingly the couplets of laminae have been called varves. The evidence upon which this assumption is based is drawn from several more or less independent sources. First of all is the analogy between the lamination found in these Eocene lake beds and that found in the deposits of modern lakes.

Perfiliev ${ }^{35}$ has shown that the black organic mud. now forming in Sakski Lake, in northern Crimea, is distinctly varved. Each varve consists of a thin black lamina of organic matter and a thicker gray lamina that consists either of fine-grained quartz sand of eolian origin or of gypsum. The black organic layers consist chiefly of minute aquatic organisms that reached their peak of production in the spring. The average thickness of these varves is 1.3 millimeters. If compacted to one-tenth of this thickness (0.13 millimeter) they would be of very nearly the same size as the varves in the marlstone beds of the Green River formation, which average 0.167 millimeter. Perfiliev, by a refined technique of sampling, was able to count with confidence 1,620 varves in a layer of ooze about 2 meters thick, and drilling by I. Mushketor in 1894 shows a thickness of lake deposits that suggests the possibility of a record as long as 16,000 years. Sakski Lake is highly saline, and the alternating laminae of gypsum and organic matter in its deposits are of unusual interest. The gypsum layers themselves are 0.1 to 0.2 millimeter thick. The writer recently found thin laminae of gypsum that alternate with laminae of organic matter in a sample of oil shale which he examined for C. H. Dane, of the United States Geological Survey. This sample came from a thin lens of oil shale in the gypsiferous series of southeastern Utah, which is of Carboniferous age. Its couplets of laminae average about 0.06 millimeter in thickness and very probably are varves.

Nipkow ${ }^{36}$ found the ooze on the bottom of the Lake of Zurich below a depth of 295 feet to consist of alternating laminae of lime-poor organic ooze and of microgranular calcite which contained but little organic matter. The organic layers were derived largely from winter maxima in the production of a plankton alga, Oscillatoria rubescens. The calcite layers he regards as having been precipitated in the summer, in part

85 Perfliev, B. V., Ten years of Soviet science, pp. 402-403, Moscow, 1927. The writer is indebted to Miss Taisia Stadnichenko for calling his attention to this article and for translating it from the Russian.

38 Nipkow, Fritz, Vorläufige Mitteilungen über Untersuchungen des Schlammab. satzes im Zürichsee: Zeitschr. Hydrologie, 1920 (cited by Collet, L. W., in Les lacs, pp. 267-269, 1925). 
through the increased temperature of the water and in part through the activity of plants. The similarity between this annual lamination and the lamination in the beds of the Green River formation is at once evident. It is germane to point out an additional minor feature of the analogy-namely, that the calcite in the organic layers is in euhedral crystals, whereas that in the other layers is not. Euhedral carbonate erystals are also more or less distinctive of the organic iaminae in the richer oil shale beds of the Green River formation. The varves in the deposits of the Lake of Zurich average about 3 millimeters in thickness, but a few are as much as 10 millimeters thick. After compaction under a load of 1,000 or 2,000 feet of rock these thicknesses would be considerably reduced. According to a rough calculation, W. W. Rubey, of the United States Geological Survey, estimated that layers of such fine-grained material would be compacted at least to one-third and perhaps to more nearly one-tenth of the thickness that they had when buried only 1 or 2 feet. Even if reduced to one-tenth these varves would indicate a rate of accumulation in the Lake of Zurich about three times as fast as that indicated by the lamination in the most nearly comparable rock of the Green River formation, the organic marlstone.

The bottom deposits of McKay Lake, Ottawa, were recently studied by Whittaker, ${ }^{37}$ who found in them a. clearly defined seasonal lamination. He found in his core samples, which were somewhat compacted, a bed of ooze 24 centimeters thick that consisted of 440 pairs of laminae. One layer of the pair was chocolatebrown and consisted of organic matter (algae of various types and a few sponge spicules); the other layer was gray and consisted largely of particles of marl washed in from the shore. The organic matter was deposited during the summer and fall, and the mineral layer was washed in from the shore during the spring rains. Thus the couplet represents an annual deposit. These paired laminae or varves are about 0.43 millimoter thick. In other parts of the core samples the varves, which could not be clearly diffentiated, were about 0.127 millimeter thick. These varved deposits formed in about 32 feet of water, the deepest part of the lake. They are plainly of the same character as the varves in the Lake of Zurich and the alternating laminae of certain beds in the Green River formation. If compacted to one-tenth of their original thickness the thicker varves of McKay Lake would be about comparable to the couplets of similar laminae in the oil-shale beds, which are 0.037 to 0.065 millimeter thick. The thinner varves of the deposits of McKay Lake, if similarly compacted, would equal almost pre-

\footnotetext{
${ }^{7}$ Whittakor, E. J., Bottom deposits of McKay Lake, Ottawa: Roy. Soc. Canad Proc. and Truns., 3d sor., vol. 16, sec. 4, pp. 141-156, 1922.
}

cisely the thinnest couplet of laminae measured in the oil shale, which is 0.014 millimeter thick.

Coit and Collet ${ }^{38}$ found that the deposits in certain parts of the lake of Geneva, Switzerland, are varved. Each varve consists of two layers, a light coarsergrained one that represents the summer deposit and a dark finer-grained one that represents the winter deposit. These couplets average about 2.5 millimeters in thickness.

Holmboe, according to Osvald, ${ }^{39}$ was able to discern varves in an algal ooze associated with peat deposits in Norway. Lundqvist, ${ }^{40}$ in commenting upon the varved algal oozes that Stalberg found in Lake Wetter, says he has found that varves are really not uncommon in the algal oozes of certain lakes in southern Sweden.

There is undoubtedly an analogy between the varves in these recent lake deposits and the rhythmic laminae in the rocks of the Green River formation.

\section{PROBABLE THICKNESS OF ANNUAL LAMINAE AS COM- PUTED FROM THE LOADS OF PRESENT STREAMS}

Another kind of evidence bearing on the time value of the rhythmic laminae in the rocks of the Green River formation is different and is, moreover, independent of that just discussed. It consists of an estimate of the probable average thickness of the deposits supplied each year to Gosiute Lake.

In large inland lakes sedimentation must be nearly equivalent to denudation within the hydrographic basin. In a closed basin this balance is manifestly perfect. But in a lake that overflows either continuously or periodically the proportion of the suspended material that is deposited depends upon several factors. In general, the greater the volume of a lake with respect to the volume of water passing through it the more efficient it is as a settling basin. Other factors, however, affect this efficiency. For example, if the mouths of streams that feed the lake are close to the outlet suspended material is more likely to be carried beyond the lake. Again, the number and size of feeding streams would be significant, for, in general, numerous small streams would distribute the detritus more uniformly and thus facilitate deposition, whereas a single large stream, especially one emptying into a shallow lake, would be likely to scour out a channel and in this way carry much of its load through to the outlet. Upper Klamath Lake, Oreg., is a good illustration. This lake has a remarkably uniform depth

${ }_{88}$ Coit, G. E., and Collet, L. W., Nouvelles recherches sur la sédimentation dans le Lac de Genève: Cong. internat. géographie Compt. rend., vol. 2, pp. 59-69, Cairo, 1925.

${ }^{8}$ Osvald, H., Till gyttjornas genetik: Sveriges geologiska undersökning Årsbok, vol. 15 , no. 3 , p. $36,1921$.

10 Lundqvist, G., Geol. Fören. Förh., Band 46, p. 193, 1924 (review of Stalberg, Nils, Nägra undersökningar av Vättergyttjans beskaffenhet: Södra Sveriges Fiskeriförening, 1923). 
of about 6 or 8 feet everywhere except along the west shore, where Klamath River has scoured out a narrow channel 20 to 40 feet deep. The current in this channel is strong enough to keep the bottom bare of any detritus except coarse sand, gravel, and boulders.

The efficiency of a lake in collecting the dissolved material in the water it receives depends in part upon the same factors that affect the deposition of the suspended material. More particularly, however, it depends upon the relation between the volume of water supplied to the lake and that lost by evaporation and upon the difference between the temperature of the lake water and that of the feeding streams. The greater the proportion of water lost by evaporation the more nearly the conditions approach those of a closed basin, wherein all the dissolved material is retained. The temperature differential between lake and stream water affects principally the carbonates, whose solubility, by reason of its dependence upon the solubility of carbon dioxide, is decreased as the temperature of the water rises; and as carbonates constitute the principal dissolved load of most streams this temperature factor is significant.

As Gosiute Lake covered a large part of its hydrographic basin and seemingly offered favorable conditions for the deposition of both suspended and dissolved material it might be reasonable to expect that sedimentation in the lake nearly equaled the erosion in its basin. Accordingly, if the thickness of the annual deposit can be calculated and expressed in terms of compacted rock it should be comparable to the observed thickness of the varves in the rocks of the Green River formation. However, as the rate of erosion during the Eocene is unknown and can only be inferred by analogy with the rate in certain modern regions this calculation involves considerable uncertainty. Also, the estimate of the relation between the size of the lake and its hydrographic basin is subject to revision, and use of that estimate may introduce still other errors. Consequently, a calculation of sedimentation based upon the present rate of erosion can not be expected to show more than the probable order of magnitude of the annual layers.

Dole and Stabler ${ }^{41}$ have assembled many determinations of the suspended and dissolved loads of rivers in practically all parts of the United States. From these figures they have computed the mean loads of streams in the several drainage basins of the country. In order to apply these data to the present problem it is necessary first to choose the subdivision of the country whose climatic conditions and topography seem most nearly to approximate those that prevailed in the basin of Gosiute Lake.

Two of the primary drainage basins outlined by Dole and Stabler ${ }^{42}$-namely, the southern IAtlantic

\footnotetext{
4 Dole, R. B., and Stabler, Herman, Papers on the conservation of water resources-Denudation: U. G. Geol. Survey Water-Supply Paper 234, pp. 78-93, 1909. ${ }^{2}$ Idem, pp. 84-87.
}

and eastern Gulf of Mexico drainage basins-together seem to offer conditions of rainfall, vegetation, and topography that coincide most nearly with those postulated for the basin of the ancient Gosiute Lake. Although the average relief is probably less in these Southern States the rainfall is probably greater, and these two factors would oppose and tend to compensate each other. If, therefore, the average loads of the streams that fed Gosiute Lake are assumed to have been the same as those carried to-day by the streams in these Southern States, the thickness of the average annual deposit upon the lake bottom can be computed from the relative areas of the lake and its hydrographic basin. (See fig. 14.) The average annual load of dissolved solids for the streams of the South Atlantic and eastern Gulf Coast States as given by Dole and Stabler ${ }^{43}$ is equivalent to 105 tons per square mile of the total drainage area, and the average annual load of suspended material is equivalent to 160 tons per square mile of drainage area. Accordingly, as the land area of the Gosiute Lake Basin was approximately 22,000 square miles, the streams working at these assumed rates would have delivered each year to the lake, partly in solution and partly in suspension, about 5,830,000 tons of material. Evenly distributed over the maximum area of the lake, about 12,300 square miles, this would be equivalent to about 474 tons per square mile. The average rock density ${ }^{44}$ of 31 different beds of very low-grade oil shale (virtually marlstone with only a small quantity of organic matter) from the Green River formation is 2.24. The average density of the rock free from organic matter may be taken as 2.3. According to this, the annual deposit of 474 tons of material per square mile of lake bottom would be equivalent to a layer 0.074 millimeter thick of rock comparable in degree of compaction, mineralogy, and porosity to the rocks of the Green River formation. This calculated thickness approximates the average thickness of the varves in the marlstone and oil-shale of the Green River formation-marlstone about 0.167 millimeter, moderately good grade oil shale about 0.065 millimeter, and richest oil shale about 0.037 millimeter.

Certain corrections should be applied to the thickness of the annual deposit as calculated here from Dole and Stabler's data, and most of these corrections would make the thickness greater. Dole and Stabler did not consider the rolling load of the streams, and presumably part of the material so moved found its way out into the fine-grained laminated deposits. Again, in making the present computations it was assumed that the material was distributed uniformly over the entire area of the lake bottom; but this is improbable, as there are reasons for believing that the lake had rather broad marginal zones beyond which the very fine material, like that considered here, would

\footnotetext{
43 Dole, R. B., and Stabler, Herman, op. cit., p. 85 .

44 Rock density is distinguished from the speciflc gravity of the minerals making up the rock in that it takes into consideration the rock's porosity.
} 
have been transported by wave and current action, thus making the thickness of the deposit in the middle of the lake greater than that on the margins. The varved rocks studied came from the middle of the basin. Considerable volcanic ash fell into the lake, and no allowance for this increment has been made. Finally, the quantity of organic matter, especially in the richer oil-shale beds, is considerable, but this was allowed for in part by assuming for the material a rock density higher than the observed rock density of many low-grade oil-shale beds.

Only one correction that should be applied would tend to reduce the thickness of the annual deposit as calculated here on the basis of present stream loads. This correction rests upon the probability that some fraction of both dissolved and suspended loads was lost from the lake by overflow. However, this loss was probably small for Gosiute Lake, because, presumably, most of the annual increment of water was removed from the enormous surface of the lake by evaporation rather than by overflow.

These corrections, though real enough, can hardly bc cvaluated quantitatively. They seem merely to indicate that the thickness of the annual deposit as calculated from Dole and Stabler's figures is probably too small. But it is very unlikely that, even in the aggregate, they would reach the same order of magnitude as the errors inherent in the assumptions which have been necessary to arrive at a figure for stream loads in the drainage basin of Gosiute Lake and upon which these calculations chiefly depend. Consequently such refinements as would be involved in applying these corrections may be neglected. But despite the crudity of the method the thickness of the annual deposit calculated in this way is of the same order of magnitude as the observed thicknesses of the varves in the Green River formation. This correspondence, therefore, also indicates that the time value of the rhy thmic lamination in the Green River beds is one year.

\section{ESTIMATED RATE OF ACCUMULATION OF THE VARVED ROCKS}

From the measurements of the varves observed in the Green River formation estimates have been made of the average rate of accumulation of each kind of rock. These are given in the table below.

Estimated rate of accumulation of the varved rocks of the Green River formation

\begin{tabular}{|c|c|c|c|}
\hline & \multicolumn{2}{|c|}{$\begin{array}{l}\text { Thickness of varves (milli- } \\
\text { meters) }\end{array}$} & \multirow{2}{*}{$\begin{array}{l}\text { Time nec- } \\
\text { essary to } \\
\text { accumulate } \\
\text { 1 foot } \\
\text { (years) }\end{array}$} \\
\hline & Range & Average & \\
\hline $\begin{array}{l}\text { Sandstone, fine grained } \\
\text { Marlstone and related rocks.- } \\
\text { Oil shale, moderately good } \\
\text { (yielding } 15 \text { to } 35 \text { gallons } \\
\text { a ton) } \\
\text { Oil shale, rich (yielding more } \\
\text { than } 35 \text { gallons a ton) } \\
\text { Weighted average........... }\end{array}$ & $\begin{array}{l}0.6-9.8 \\
.014-.370 \\
.03-.114 \\
.014-.153 \\
-.0 .0\end{array}$ & $\begin{array}{l}.065 \\
\\
.037 \\
.18\end{array}$ & $\begin{array}{l}4,700 \\
8,200 \\
2,200\end{array}$ \\
\hline
\end{tabular}

\section{EFFECT OF NATURAL RHYTHMS ON THE CHARACTER OF SEDIMENTS}

In any attempt to evaluate thin rhythmic lamination the power of various natural rhythms ${ }^{45}$ to affect the character of sediments should be considered.

Periodic storms, as for example the cyclonic storms of to-day, might perhaps have produced a rhythmic lamination in the lake deposits. Storm waves in stirring up the bottom ooze would have thrown it into suspension, from which it would have settled gradually, and as the ooze consisted of particles of calcite and of organic matter, whose respective specific gravities are very different, a density stratification must have resulted. Moreover, this stratification would have been similar to that observed in the rocks of the Green River formation, for the lower layer would have consisted chiefly of the heavier carbonate particles and the upper layer chiefly of organic matter. But when the next storm occurred this same material, or at least part of it, plus whatever sediment had since come down, must have been again thrown into suspension. Upon settling it would resume a density stratification, but despite the fact that there had been two storms only one couplet of laminae would have been perfect, and it would have rested upon the remnants of the preceding couplet.

For storms to have produced a regular series of uniformly perfect pairs of laminae such as that illustrated in Plate 11 it is necessary to postulate one or the other of two conditions-(1) that each successive storm stirred up only the ooze that had accumulated since the completion of the preceding couplet of laminae, or that it stirred up the fresh supply and in addition one or more complete couplets of luminae, but never only part of a couplet; or (2) that between the formation of each couplet of laminae and the next storm the stratified material became so much indurated that it was unaffected by subsequent storm waves. Either of these necessary postulates seems to the writer adequate to rule out periodic storms as agents competent to produce the regular, uniform series of paired laminae observed in the rocks of the Green River formation. Moreover, there is a small but significant difference between pure density stratification and that observed in most beds in the Green River formation. In pure density stratification the grain size should diminish regularly upward from the base of each pair of laminae, but the grains in most laminae in the Green River beds are practically unsorted, even though the distinction between the layers rich in organic matter and those poor in organic matter is very sharp. If the material had been thrown into suspension in saline water coagulation would have prevented a clean separation of the various sizes of mineral grains, but at the same time it would just as surely have prevented a distinct separation of organic and mineral constituents.

45 Barrell, Joseph, Rhythms and the measurement of geologic time: Geol. Soc. America Bull., vol. 28, pp. 824-834, 1917. 
Barrell ${ }^{46}$ considered rhythms of another kind, which he called orbital rhythms and which depend on motions in the solar system. Of this sort only two, the alternation of day and night and of summer and winter, are short enough to be considered here. Tides in the lake obviously must have been too slight to affect the sedimentary record. Diurnal temperature changes might conceivably have been large, and evaporation rates, which depend in part on the temperature, would have fluctuated in a corresponding manner; yet it is difficult to see how these changes could have affected perceptibly the rate of deposition, arrangement, or composition of the sediments.

The seasonal changes, however, have an evident effect upon the factors that influence sedimentation. Erosion rates and consequently rates of supply of material vary with the changing rainfall. The rate at which carbonates precipitate depends, in part at least, upon the temperature of the water, and the temperature of the water varies chiefly with the seasons. The rates of growth of planktonic organisms are controlled closely by temperature, and consequently the supply of organic matter in lakes also changes with the seasons. Furthermore, the thermal stratification in lakes (see $\mathrm{p}$. 102), which is a distinctly seasonal phenomenon, may have a marked influence upon the differential settling rates of various kinds of sediment. Apparently, therefore, the march of the seasons is the only natural cycle of the right order of magnitude which combines pronounced effects upon the factors controlling sedimentation with the regularity necessary to explain adequately the long series of thin, uniform laminae found in the rocks of the Green River formation. The hypothesis that the couplets of laminae represent an annual rhythm and are therefore varves affords also a satisfactory basis for explanation of the origin of their bipartite character.

\section{ORIGIN OF THE VARVES}

\section{BIOCHEMICAL REACTIONS}

Of the three hypotheses that have been considered to explain the rhythmic alternation of carbonate and organic laminae of the varves in the Green River formation one depends upon biochemical reactions.

Abundant evidence has been assembled to prove conclusively that the organic matter in the oil shale passed through a stage of putrefaction. The ooze or sapropel which was later lithified into oil shale must have been wholly analogous to the black fetid organic oozes now forming in both fresh and salt lakes. The characteristics of such lacustrine ooze or "Faulschlamm" have been described with con-

\footnotetext{
60 Barrell, Joseph, op. cit., pp. 827-829.
}

siderable detail by Naumann, ${ }^{47}$ Potonie, ${ }^{48}$ Nadson, ${ }^{49}$ Wesenberg-Lund, ${ }^{50}$ and others. In the microbian decomposition of such ooze the albumin is broken down, and among other compounds ammonia and hydrogen sulphide are formed. The ammonia immediately reacts with the $\mathrm{HCO}_{3}$ ions in solution and precipitates the normal carbonates of calcium and magnesium. The products of this reaction assume particular significance for the problem in hand as they are interpreted by Nadson ${ }^{51}$ in describing the bottom deposits of Weissowo-Salzee, which is near the city of Slawjansk, Kharkof, Russia. He isolated four bacteria and three fungi which play the principal partin the formation of the fetid black oozein that lake. - These organisms are Bacillus mycoides Flügge, Proteus vulgaris Hauser, Bacterium albo-luteum Nadson, Bacillus salinus Nadson, Actinomyces alba Gasperini, $A$. verrucosus Nadson, and $A$. roseolus Nadson. They all bring about the decomposition of albumin with the release of abundant ammonia and hydrogen sulphide. Nadson finds that by the activity of these organisms thin laminae of calcium and magnesium carbonates are deposited on the surface of the ooze. These laminae of microcrystalline carbonates are apparently analogous to those in the oil shale and marlstone. However, to explain why these laminae of mineral grains alternate with organic layers, as they do in the oil shale of the Green River formation, some periodic change of rate, either in the activity of the organisms or in the supply of the organic and inorganic constituents, must be postulated. Thus this hypothesis is not entirely adequate to explain the dual lamination of the varves without some such periodicity of supply, but it provides another mechanism by which to explain the occurrence of thin indefinite lenses of microgranular carbonates mixed with organic matter. Lenses of this sort obscure the varves in a few beds of moderately good oil shale. (See pl. 13, B.)

\section{DIFFERENTIAL RATE OF SETTLING}

Another hypothesis to account for the rhythmic alternation in the varves depends upon the difference in density between the organic matter and the carbonate grains.

The greater part of the organic matter presumably came down as a rain of minute planktonic organisms

47 Naumann, Einar, Die Bodenablagerungen des Süsswassers: Archiv für Hydrobiologie und Planktonkunde, vol. 13, pp. 100-186, 1921-22.

48 Potonié, H., Die rezenten Kaustobiolithe und ihre Lagerstatten: K. preuss. geol. Landesanstalt Abh., vol. 55, pp. 9-36, 49-232, 1908.

${ }^{40}$ Nadson, S., Die Mikroorganismen als geologische Faktoren: Bot. Centralbl, vol. 96, pp. $591-593,1904$

${ }_{50}$ Wesenberg-Lund, C., Lake lime, pes ore, and lake gyttja in Danish inland lakes: Dansk geol. Foren., No. 7, pp. 159-168, 1901.

${ }^{31}$ Nadson, S., op. cit., pp, 591-593. 


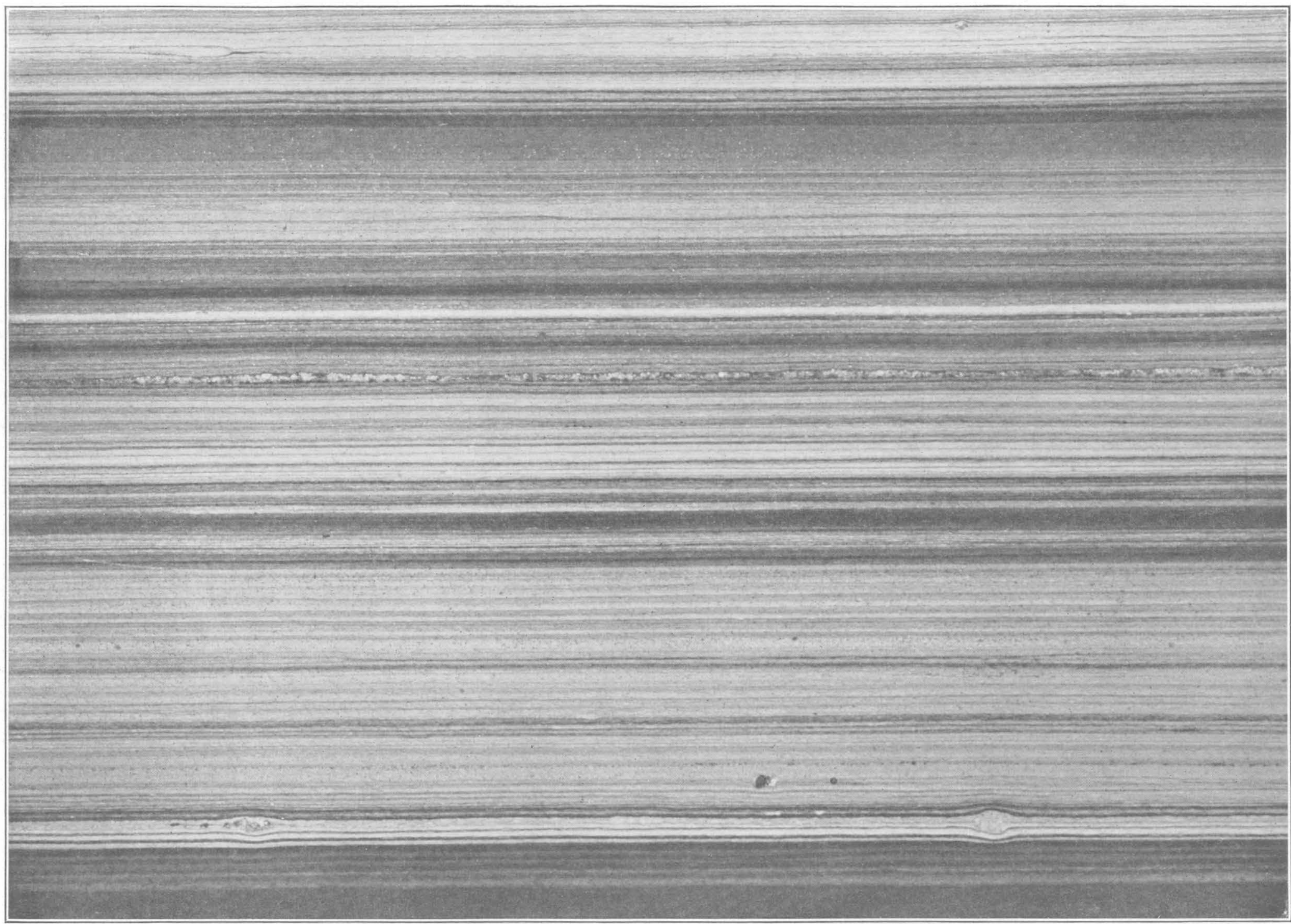

PHOTOGRAPH OF A POLISHED SPECIMEN OF ORGANIC MARLSTONE SHOWING TYPICAL VARVES OF THE GREEN RIVER FORMATION

The darker parts of the rock contain the most organic matter. At the base of the broad light-colored band that crosses the middle of the photograph the individual laminae of the varves can
be most readily distinguished. Specimen from a bed about 1,300 feet above the base of the formation on Clear Creek, in sec. 9 , T. $5 \mathrm{~S}$., R. $98 \mathrm{~W}$., Garfield County, Colo. Enlarged 4. diameters 


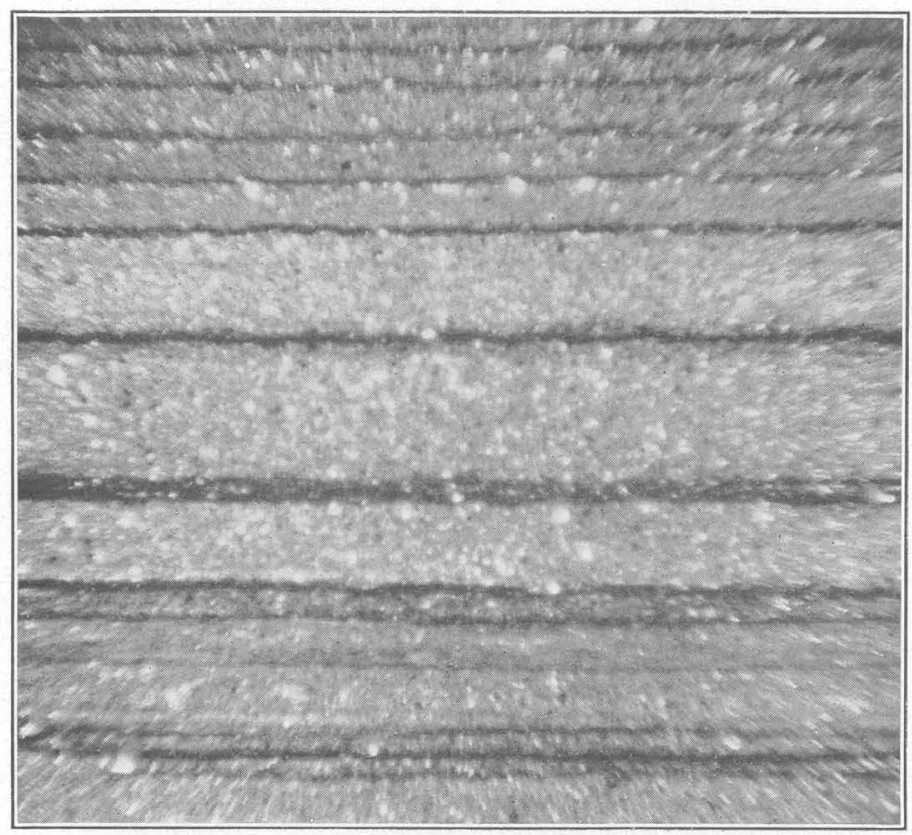

A. PHOTOMICROGRAPH OF A FINE-GRAINED LIMY SANDSTONE SHOWING THICK VARVES

The light bands are sandy and unusually thick. The dark bands consist largely of organic matter. Specimen from a bed in the upper part of the Green River
formation at the junction of Parachute Creek and East Middle Fork of Parachute formation at the junction of Parachute Creek and East Middle Fork of Parachute
Creek in sec. 18, T. 5 S., R. 95 W., Garfield County, Colo. Enlarged 37 diameters

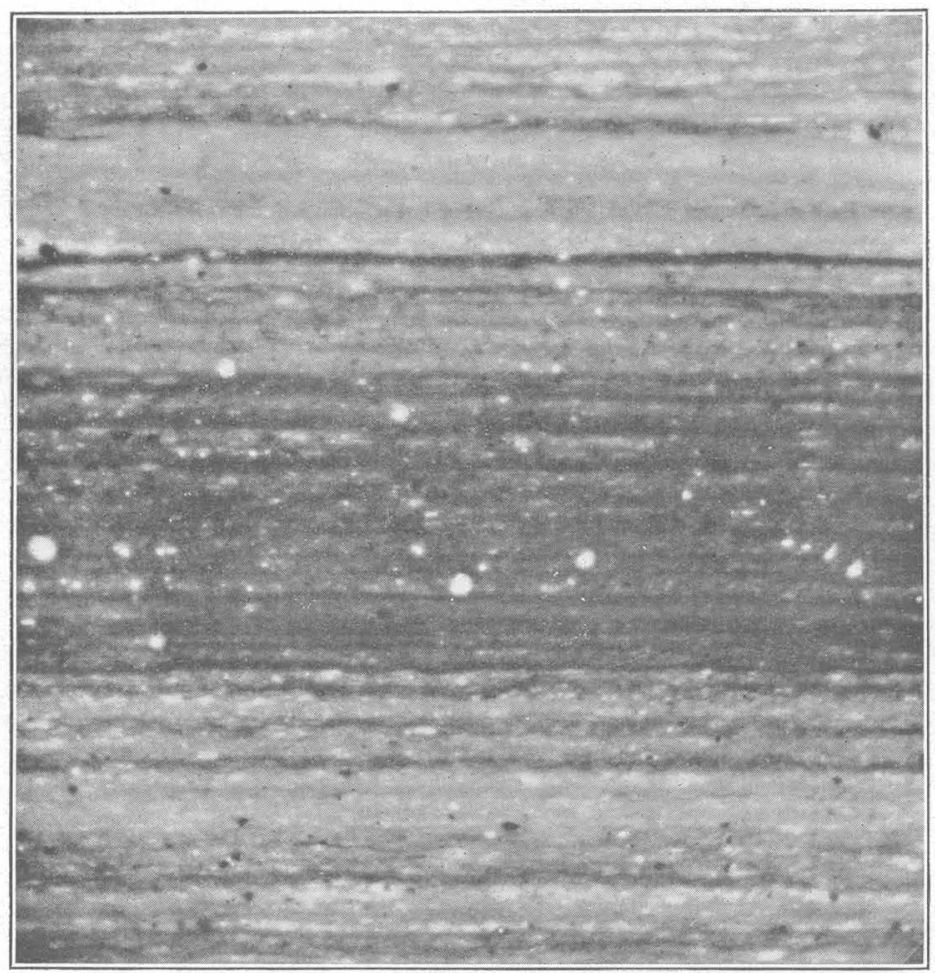

B. PHOTOMICROGRAPH OF A PART OF THE ORGANIC MARLSTONE SHOWN IN PLATE 11, ILLUSTRATING THE REGULAR SPACING OF THE DARK ORGANIC LAMINAE

The thin section was cut abnormally thick so as to bring out the more feebly colored organic layers. Enlarged 18 diameters 


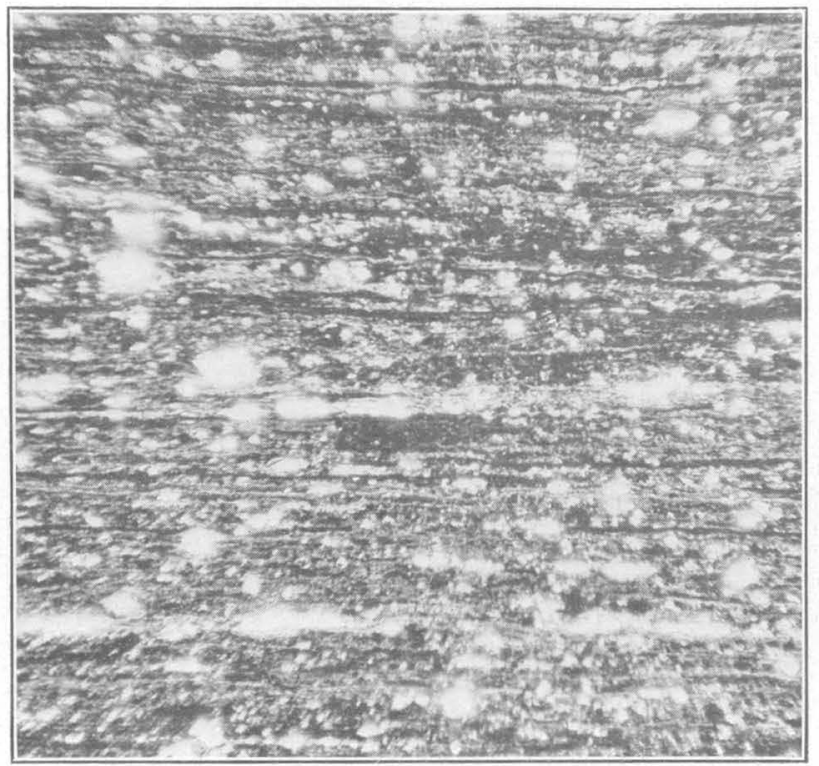

A. PHOTOMICROGRAPH SHOWING THIN VARVES IN A VERY RICH OIL SHALE

From the Mahogany Ledge near the head of Clear Creek, in sec, 9, T. 5 S., R. 98 W., Garfield County, Colo. The black parts are organic matter, and the light-gray areas are mineral grains. Enlarged 54 diameters

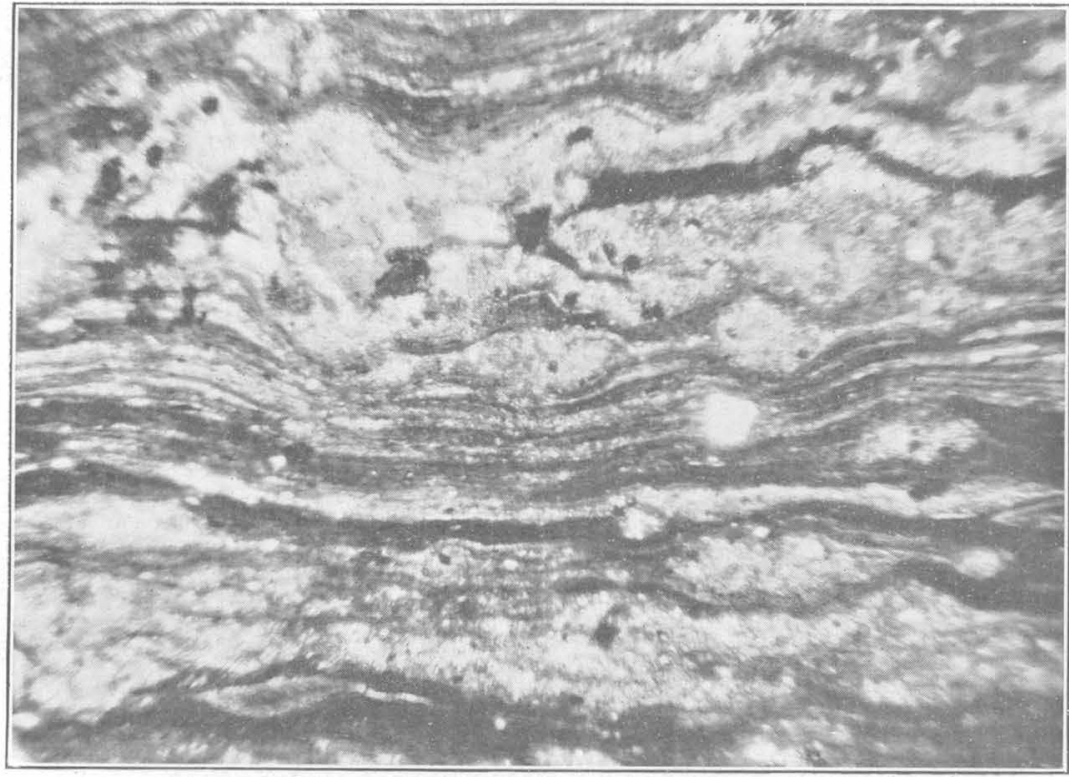

B. PHOTOMICROGRAPH OF A RICH OIL SHALE SHOWING GROUPS OF VARVES DISTORTED BY SMALL CONCRETIONARY LENSES OF CARBONATE GRAINS

Enlarged 54 diameters 


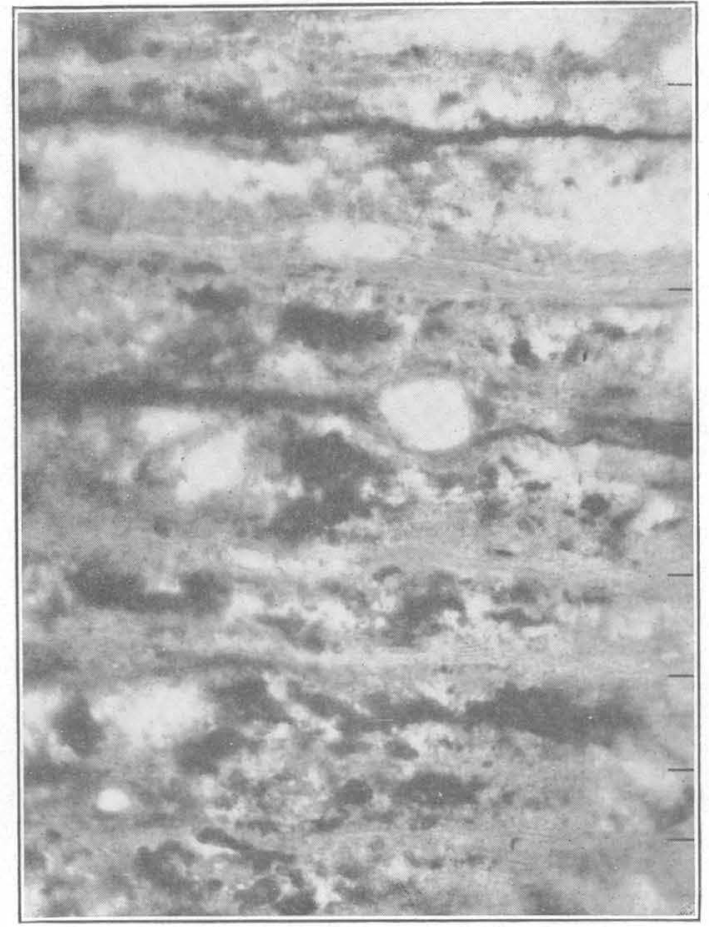

4. PHOTOMICROGRAPH SHOWING DETAL OF THE VARVES IN THE RICH OLL SHALE ILLUSTRATED IN PLATE 13, $A$

The organic laminae, indicated by marks in the margin, are themselves finely laminated. The mineral laminae contain con their coarser grain and greater thickness. Fnlarged 320

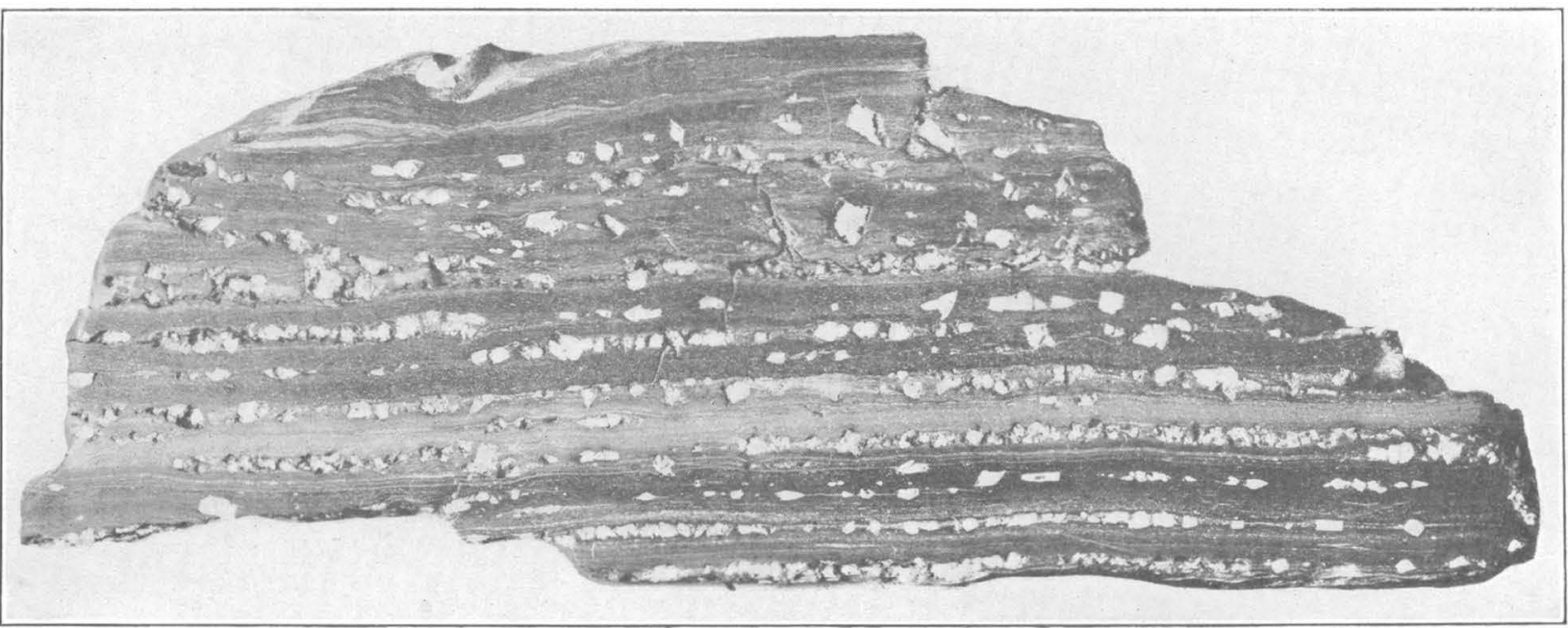

B. PHOTOGRAPH OF A POLISHED SPECIMEN OF MODERATELY RICH OIL SHALE

From Green River, Wyo. Shows regularly spaced layers of calcite-filled glauberite (?) cavities. Natural size 
which might have ranged from 1 or 2 microns to several millimeters in maximum dimension, though if an analogy with Lake Mendota in Wisconsin is significant it might be inferred that most of the organisms were less than 60 microns in diameter. Birge and Juday ${ }^{52}$ define the nannoplankton as all the organisms which will pass through No. 20 silk bolting cloth (whose openings average about 60 microns in diameter) and state that in Lake Mendota these minute organisms constituted about five times as much organic matter as the larger net plankton.

It is reasonable to believe that the precipitation of carbonates accompanied the sedimentation of the remains of plankton organisms. And if the assumptions are made that organisms and carbonate grains began to settle from the same water stratum, that the particles of both sorts of material settled as spheres, that the carbonate grains averaged about 5 microns in diameter (their present size), and that the organisms averaged about 50 microns in diameter and had an average specific gravity of 1.05 , then the variables of Stokes's law ${ }^{53}$ show that the carbonate grains, despite their small size, must have settled many times more rapidly than the lighter organic matter. Consequently there would have been complete separation of the constituents into two layers even in shallow water. Actually, however, many plankton organisms are not spherical but flattened, and others have various appendages to facilitate floating; furthermore, such organisms immediately after death are subject to the attacks of other organisms that tend to disintegrate and decompose them as they settle toward the bottom. These two factors would combine to accentuate a density stratification. But if the deposition of both constituents was continuous then they must have accumulated together in an unstratified mixture after the period required for the first particles of the more slowly settling material to reach bottom. Clearly, differential rate of settling was a factor, yet as the varves consist of laminae rich in mineral matter alternating with laminae rich in organic matter it does not account for all the facts unless a periodic supply of either or both constituents is assumed.

\section{SEASONAL CHANGE IN RATE OR KIND OF DEPOSITION}

The third hypothesis advanced to explain the regular alternation of the material in the varves assumes a periodic change in rate either of the activity of microorganisms or of supply of organic and inorganic constituents.

In inland lakes there is a periodic production of aquatic organisms, which, if the diatoms are ignored, reaches its maximum in the summer. For the purpose in hand the diatoms can well be ignored, for none

ss Birge, E. A., and Juday, O., The inland lakes of Wisconsin: Wisconsin Geol and Nat. Hist. Survey Bull. 64, pp. 63, 93, 1922.

os Twonhofol, W. H., and others, Treatise on sedimentation, p. 40, 1926. have been found in the Green River formation. The maximum growth of most other organisms occurs in summer and falls off to a negligible minimum in winter. In lime-rich lakes finely divided calcium carbonate is precipitated in summer but only slightly in winter; it may even be partly dissolved in winter. The maximum precipitation in summer may be ascribed to two principal causes-(1) the increased temperature of the water, which reduces the solubility of carbon dioxide and consequently the solubility of calcirm carbonate, and (2) the activity of submerged green aquatic plants, which abstract carbon dioxide from the water and thereby also precipitate calcium carbonate. Hassack ${ }^{54}$ and later Chambers ${ }^{55}$ demonstrated how effectively algae can remove carbon dioxide from solutions of calcium bicarbonate. Powell ${ }^{56}$ pointed out the value of plankton algae in precipitating carbonates from reservoir waters. Nauman, ${ }^{57}$ Wesenberg-Lund, ${ }^{58}$ Thienemann, ${ }^{59}$ and others have emphasized the large production of aquatic organisms, both plant and animal, consistently found in lakes of moderate depth which contain an abundance of calcium in solution. Thus in certain modern lakes there is a pulsating supply of both organic matter and finely divided calcium carbonate available for sedimentation. Moreover, the pulses are seasonal, and as was pointed out on pages 96 and 97 , they lead to the formation of varves remarkably similar to those of the Green River formation.

This similarity suggests the likelihood that the couplets of laminae in the rocks of the Green River formation were produced by a comparable pulsating supply of materials in Gosiute and Uinta Lakes.

If it is assumed that the greater part of the rainfall came in the winter and that the summers were relatively dry and warm, then the streams would have brought to the lake the greater part of their annual supply of dissolved and suspended mineral matter during the winter and spring, when the temperature of the lake water probably did not differ greatly from that of the streams. But during the summer the temperature of at least the surface layer of lake water must have risen, and the higher it became the more it must have favored the precipitation of carbonates and also the growth of minute aquiatic organisms. . Thus it scems that large supplies of both organic matter and carbonate particles would have been produced at the same time of the year. Yet probably the maximum "pre-

34 Hassack, Carl, Über das Verhältniss von Pflanzen zu Bicarbonaten und über Kalkincrustation: Bot. Inst. Tubingen. Untersuchungen, vol. 2 , pp: $467=473,1888$. ss Chambers, C. O., The relation of algae to dissolved oxygen and carbon dioxide with special reference to carbonates: Missouri Bot. Garden Ann. Rept., vol. 23, pp. 178-192, 1912.

${ }_{56}$ Powell, S. T., The effect of algae on bicarbonates in shallow reservoirs: Am. Waterworks Assoc. Jour., vol. 2, pp. 703-708, 1915.

oi Nauman, Einar, Die Bodenablagerungen des Süsswassers: Archiv für Hydrobiologie und Planktonkunde, vol. 13, pp. 115-117, 1922-23.

ss Wesenberg-Lund, C., Lake lime, pea ore, and lake gyttja in Danish inland lakes; Dansk geol. Foren., No. 7, pp. 164-167, 1901.

${ }^{30}$ Thienemann, August, Seetypen: Naturwiss. Wochenschr., vol. 18, p. 345, 1921. 
cipitation of carbonates occurred, as it does now in many lakes, rather early in the summer, while the temperature of the water was rising most rapidly toward the general high summer level. If another analogy with modern lakes is applicable, probably the peak in the plankton production came near the middle or even late in the summer. These conditions would have been about optimum for the deposition of varved sediments like those of the Green River formation. The carbonates, by reason of their greater density, would have fallen rapidly, whereas the organic matter would lag considerably and so the greater part of it would come to lie above the carbonate layer.

If these ancient lakes were deep enough to permit a thermal stratification of the water during the summer, and this seems probable for certain of their stages, then the separation of mineral and organic matter at the lake bottom would have been nearly complete, for the density of the cold lower layer should have been great enough to retard the rate of fall of small particles of organic matter. In certain modern lakes where the temperatures of the lower layers of water are lower and the densities therefore greater than they probably ever were in Gosiute and Uinta Lakes, this retarding effect is remarkable. Forel ${ }^{60}$ says that in the Lake of Geneva the carapaces of various Entomostraca remain suspended for long periods as an opaque cloud at the thermocline-that is, the boundary between the hypolimnion, or lower stratum, in which the water is virtually stagnant, and the epilimnion, or surface stratum, in which the water is free to circulate. Brönsted and Wesenberg-Lund ${ }^{61}$ found that during the summer stagnation of certain Danish lakes there was very little organic detritus above the thermocline, but below the thermocline there were vast quantities, which increased in amount downward. A free translation of their remarks upon the organic detritus in the hypolimnion follows:

Often the samples [of water] were colored light brown, and the detritus exceeded by far the living plankton. Very probably it becomes more or less dissolved in the deeper layers. It was frequently observed that the deepest water samples were colored light brown, and often the quantity of detritus was so great that it seemed as if the water sampler had been dragged along the bottom.

This much dissolved organic matter would probably make the water acid and thus tend to dissolve the carbonates already precipitated, but, as Kindle ${ }^{62}$ points out in discussing the relations between the thermal stratification of McKay Lake, Ottawa, and the composition of the varves, the later increment of

60 Forel, F, A, Le léman, vol 1, p. 118, 1892.

61 Brönsted, J. N., and Wesenberg-Lund, C., Chemisch-physikikalische Untersuchungen der dänischen Gewässer: Internat. Revue der gesamten Hydrobiologie u. Hydrographie, Band 4, Hefte 5 and 6, p. 469, 1912.

62 Kindle, E. M. The rôle of thermal stratification in lacustrine sedimentation: Roy. Soc. Canada Trans., vol. 21, sec. 4, p. 17, 1927. plankton débris would very likely protect the carbonates from this slightly acid water.

Plainly, however, the separation between the mineral and organic constituents in the varves of the Green River formation is not perfect; clay minerals, other clastic minerals, and carbonate grains are scattered through the organic layers, and organic matter occurs in the mineral-rich layers. It seems more reasonable, therefore, to postulate a more or less continuous sedimentation of mineral and organic constituents with first a peak in the production of the carbonates and then a peak in the production of plankton. Evidently it is possible that these peaks might be nearly or indeed quite coincident and still give rise to varved deposits, because of the different rate of settling of the two classes of material. That there may have been more than a single peak in the plankton production seems probable, to judge from the successive maxima of plankton in many modern lakes. Moreover, there is even a suggestion of this in the excessively thin laminae of differently colored organic matter that were observed within the organic parts of the varves of a few rich oil-shale beds. (See pl. 14, A.)

The hypothesis of seasonal change in the rate or kind of deposition advanced to explain the varves in the organic marlstone and oil shale appears to explain equally well the thicker varves in the beds of finegrained limy sandstone. In fact, these varves even appear to provide independent evidence that. the major part of the rainfall occurred at one season and at a period preceding the peak in the production of organic matter. The sharp contact between successive varves and the concentration of the sand and silt in the basal part of each varve seem to indicate that after a period of quiet, during which the organic matter accumulated and the finest mineral particles settled, there was a sudden influx of detrital material. This supply of detritus apparently started with maximum intensity and thereafter diminished until the organic matter began to accumulate, when it was barely perceptible. Accordingly, the structure of these varves suggests a period of considerable rainfall, during which erosion was relatively rapid and the streams were loaded, followed by a period of slackened rainfall and general absence of storminess, during which the production of plankton reached its maximum. and the finest suspended material settled. This particular varve structure, however, might in itself be quite as well explained by assuming repeated storms or repeated influx of detrital material within a year if the periods of increased supply were separated by intervals long enough for the finest material to settle; but the transition within the same series from varves of this type to varves typical of the marlstone beds, in which the supply of organic matter seems probably. to have been seasonal, argues against this 
explanation. Moreover, this transition appears to indicate that the organic part of the sandy varves is homologous with the organic part of the marlstone varves, and it therefore implies that the organic part of the sandy varves likewise represents a definite season.

CONDITIONS AFFECTING THE PRESERVATION OF - THE
VARVES

The preservation of varves, particularly varves like those in the beds of marlstone, whose bounding planes are almost geometrically perfect, implies certain requirements as to depth and circulation of the water and as to the population of the ooze at the time of deposition. It is evident that there could have been no wave action and only the most feeble currents in the bottom region of the lake. Currents in the surface layers of the water, on the contrary, were apparently necessary to supply the small but consistent quantity of clastic material (clay minerals, quartz, feldspar, etc.) found in the varved rocks. But this condition, in which the surface water circulated more or less but the deeper water did not, strongly suggests that the water of these ancient lakes was thermally stratified. Other evidence also favors this hypothesis. The original ooze of the varved rocks could not have harbored an active bottom fauna of worms, larvae, crustaceans, and the like, for surely these organisms would have destroyed the perfection of the lamination. Nipkow ${ }^{63}$ found that only the ooze below the 90 -meter (295-foot) contour in the Lake of Zurich was laminated. Above that level the water is oxygenated, and an active fauna keeps the bottom stirred up and thus prevents stratification.

Lenz ${ }^{64}$ sampled the deposits of 12 different lakes in Holstein, each of which had a large production of plankton and consequently also thick deposits of putrescent organic ooze. Yet none of the deposits were laminated. He attributed this largely to the activity of worms, insect larvae, and similar organisms, which burrowed in the ooze, fed upon it, and thoroughly worked it over. Futhermore, the consistent presence of finely granular pyrite in the varves of the Green River deposits strengthens the notion that these deposits accumulated under reducing conditions such as prevail generally in the stagnant hypolimnion of modern lakes that are thermally stratified. One is tempted to go further and say not only that the water of these ancient lakes was thermally stratified but that the stratification was normal-that is, the epilimnion was warmer than the hypolimnion-and moreover that this stratification persisted and was not interrupted by spring and autumn overturns and the establishment of

os Nipkow, Fritz, Vorlkufnge Mitteilungen uber Untersuchungen des Schlammabsatzos im Zürichseo: Zeitschr. Hydrologie, 1920 (reviewed by Hummel, K., Neues Jahrb., 1021, Band 2, p. 180).

of Lenz, Fr., Schlammschichtung in Binnenseen: Naturwiss. Wochenschr., vol. 18 , pp. 327-329, 1921 . inverse stratification during the winter. In an inverse stratification the temperature of the epilimnion ranges between $0^{\circ}$ and $4^{\circ} \mathrm{C}$., whereas the temperature of the hypolimnion is $4^{\circ} \mathrm{C}$, , or very close to it. Spring and autumn overturns, during which all the water in a lake goes into circulation, seem to be precluded by the consistent perfection of the varves. Circulation reaching the lake bottom, it seems, would surely have distributed ooze whose constituent particles were so small, for, according to Lenz, ${ }^{65}$ Thienemann found in the surface water particles of organic mud which were brought up from the bottom by the vigorous circulation at times of overturn.

The position of the thermocline in modern lakes varies so much and depends upon so many factors that its depth in these ancient lakes during the periods in which the varved deposits accumulated is difficult to estimate. The mean velocity of the wind is clearly an important factor determining the depth to the thermocline, for it governs the strength of the water circulation; and as these lakes were broad they must have felt the full effect of the winds. But according to Brooks, ${ }^{66}$ the early part of the Tertiary period was not a time of great storminess, though apparently there were brief and somewhat violent squalls. Therefore, despite the great area of these lakes, it is perhaps unnecessary to postulate a deep thermocline so as to allow for a vigorous circulation in the epilimnion. Without continued circulation to distribute the sun's heat that reached the lake surface the epilimnion may conceivably have been very shallow and may have been measured in feet rather than tens of feet, as in many modern lakes in temperate zones. Thus, it seems, these ancient lakes, even though large and only 75 or 100 feet deep, may nevertheless have had a distinct thermal stratification. Clearly this is nothing more than a guess at what seems to be a reasonable minimum depth at which perfect lamination in ooze might have originated and have been preserved in bodies of water as large as the ancient Gosiute and Uinta Lakes.

\section{CYCLES OF GREATER MAGNITUDE}

Three cycles of greater average length than the varve cycle are suggested by fairly regular recurrent variations in the thickness of the varves and in the thickness and character of certain beds and by the fairly regular spacing of certain layers containing salt molds. The shortest of these cycles appears to correspond to the cycle of sun-spot numbers, and the longest suggests the cycle of the precession of the equinoxes, but the cycle of intermediate length corresponds with no wellestablished rhythm.

${ }^{63}$ Lenz, Fr., op. cit., p. 329. ${ }^{66}$ Brooks, C. E. P., Climate through the ages, pp. 57, 187, 224, New York, R. V.
Coleman, 1926 . 


\section{CYCLE OF SUN-SPOT NUMBERS}

Recurrent groups of unusually thick varves are evident in the varve series that are 30 years or more long. (See fig. 15.) The average interval between these peaks is a little less than 12 years, but the length of individual intervals ranges from about 7 to about 18 years. The average interval between sun-spot maxima is a little more than 11 years, though the period ranges from about 7 to more than 16 years. ${ }^{67}$ Plainly the correspondence between these two cycles is not perfect. Nevertheless, it is close enough to be suggestive and seems to merit consideration, especially as there are fairly good theoretical reasons for linking variations in the sun's energy with the physical conditions of the lakes that would affect the character of the varves. Brooks ${ }^{68}$ has shown that there is a much closer correlation between sun-spot numbers and the levels of certain large lakes in central Africa than between the rainfall and the lake levels. This interrelation between variations in the sun's energy, of which the number of sun spots is an index, and the lake levels depends upon evaporation, which accounts for about 94 per cent of the water lost from the basin in a lake; and the shallower the lake and the broader its littoral zones the more pronounced this effect would be. It has already been pointed out in considering the origin of the varves that the rate of accumulation of both carbonates and organic matter varied directly with and depended chiefly upon the rise and fall of the water temperature. Hence, if at times of sun-spot minima these ancient lakes were abnormally low, they should also have been abnormally warm, and the rates of accumulation of carbonates and organic matter should also have increased accordingly, with the result that the varves for those years should be abnormally thick. In the same way varves corresponding to years of sun-spot maxima should be thinner than usual or perhaps should contain more clastic material because of the increased raininess. This explanation implies that if a real connection existed between solar activity and sedimentation during the Green River epoch, then the peaks on the curves shown in Figure 15 would correspond to intervals of sun-spot minima. Varves consisting predominantly of physicochemical deposits and of plankton débris, whose deposition depends largely upon the physical conditions within
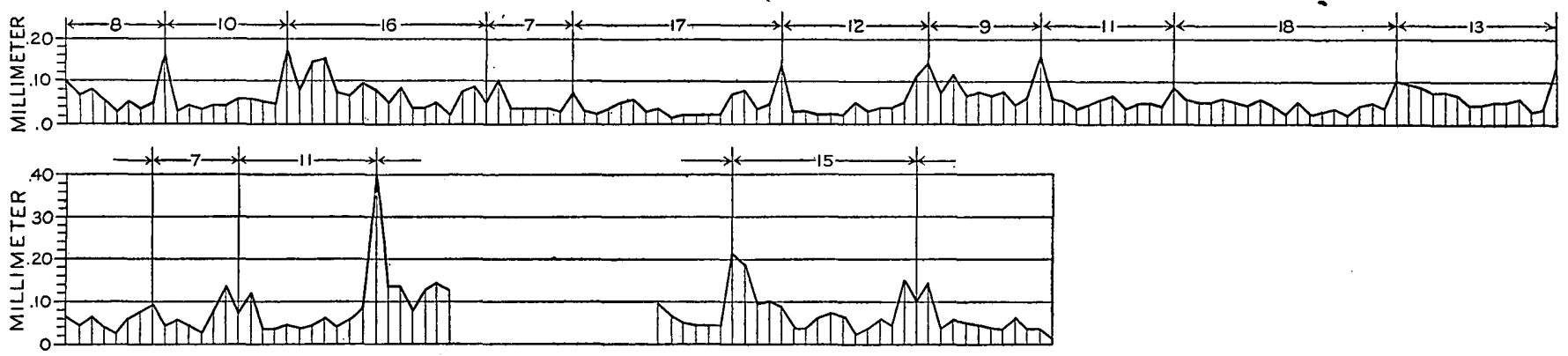

Figure 15.-Curves showing the recurrent peaks in the total thickness of the varves in an organic marlstone from Clear Creek, Colo. The numbers indicate the number of varves that separate the recurrent peaks.

of Lake Victoria, the other 6 per cent being the discharge from the lake. Brooks ${ }^{69}$ says:

The chief factor in the amount of evaporation, however, is not rainfall but solar conditions. The researches of $W$. Köppen and others have established beyond doubt that there is a close connection between sun-spot numbers and tropical temperatures, the latter being $1.1^{\circ} \mathrm{F}$. higher at spot minima than at spot maxima. It is reasonable to conclude that the higher the temperature the greater the evaporation; hence at spot minima evaporation will be increased and the level of the lake will fall, while at spot maxima evaporation will be decreased and the level of the lake will rise. This relationship, as we have seen, is so intimate that it gives correlation coefficients of between 0.8 and 0.9 .

Perfect correspondence would be represented by a coefficient of 1.0 .

A change of level might be expected to have a distinct effect upon the mean temperature of the water

\footnotetext{
a7 Moulton, F. R An introduction to astronomy, p. 383, 1916.

${ }_{68}$ Brooks, C. E. P., Variations in the levels of the central African Lakes Victoria and Albert: Great Britain Meteorological Office Geophys. Mem. 20, pp. 337-344, 1923.

${ }^{69}$ Idem, p. 343
}

the lake itself, are clearly better suited to reflect the pulse of the solar cycle than varves consisting predominantly of clastic material, whose ultimate sedimentation can be connected with changes in solar radiation chiefly through the very indirect circuit of rainfall, erosion, transportation, and finally distribution within the lake. Thus, from purely theoretical considerations, the varves in the organic marlstone and oil shale of the Green River formation might be expected to show with more or less fidelity the effect of cyclic changes in solar energy. According to Brooks, ${ }^{70}$ the opposition between sun spots and temperature is greatest in the Tropics, but diminishes and grows less regular in temperate latitudes. On the other hand, L. Mecking ${ }^{71}$ found that the influence of the sun's activity upon the temperature at the earth's surface depends upon local geographic position and upon the season-for example, in the interior of North America the effect of the sun-

70 Brooks, C. E. P., Climate through the ages, p. 102, 1926.

${ }^{7}$ Hann, Julius, and Süring, R. J., Lehrbuch der Meteorologie, p. 656, Leipzig, 1926 
spot numbers on the temperature is uncommonly strong.

Indications of the sun-spot cycle have been found in other varved sediments. Perfiliev ${ }^{72}$ found in the varves of the black mud in Sakski Lake of northern Crimea evidence of cyclic changes whose average period was between 10 and 11 years. These he believes are to be correlated with the cycle of sun-spot numbers. Brooks ${ }^{73}$ says that according to T. W. E. David the upper Carboniferous glacial varves of Australia appenr to show an 11-year periodicity.

\section{CYCLE OF THE PRECESSION OF THE EQUINOXES}

Cyclic changes in the conditions of sedimentation of approximately the same average period as the resultant of the change of eccentricity of the earth's orbit and the precession of the equinoxes are indicated by a regular alternation of beds of oil shale and organic marlstone. These rhythmically alternating beds occur in four groups at three localities in Garfield County, Colo. One group is in a section measured near the hend of East Middle Fork of Parachute Creek, in sec. 16, T. 5 S., R. $95 \mathrm{~W}$.; the second group is in a section measured on the north side of Cathedral Creek, approximately in sec. 26 , T. 3 S., R. 99 W.; and the third is, about 50 feet lower in the Cathedral Creek section. These sections of the Green River formation are complete and were measured by the writer and his assistant, R. D. Ohrenschall, in 1925. The fourth group of rhythmically spaced beds is a part of a section measured by the assistants of Fred Carrol on Clear Creek in sec. 9, T. 5 S., R. 98 W., Garfield County, Colo., and submitted to the Department of the Interior at a hearing on oil shale held before the Secretary on December 1, 1926. The upper group of beds in the Cathedral Creek section, the group in the Parachute Creek section, and the group in the Clear Creek section may be precisely correlated, as they are situated respectively about 150 , 160 , and 130 feet above a certain thin bed that is locally known as the "Mahogany marker." This marker bed, heretofore generally regarded as a finegrained sandstone, has been found to be a bed of zeolitized volcanic ash. ${ }^{74}$

The thickness of these regularly spaced oil-shale and marlstone beds multiplied by the average rate of accumulation of each kind of rock serves as an approximate measure of the cyclic changes in sedimentation. Most of the organic marlstone beds are about 6 feet thick, though the extreme range in thickness is from 3.8 to 8.8 feet. The oil-shale beds range in thickness from 0.6 to 3.0 feet. In a general way the thickness of the beds, particularly the oil shale, diminishes with

\footnotetext{
78 Perfiliov, B. V., Ten years of Soviet science, p. 403, Moscow, 1927.

78 Brooks, C. E. P., Climate through the ages, p. 192, 1926.

7 Bradley, W. H., The occurrence and origin of analcite and meerschaum beds in the Green River formation of Utah, Colorado, and Wyoming: U. S. Geol. Survey Prof. Paper 158, pp. 2-3, 1929.
}

increasing content of organic matter. However, the significance of these groups of beds lies in the regularity of the alternation and in the uniformity of character and relative thickness of the two distinctly different types of rock rather than in the absolute thickness of the beds. The estimated rates of accumulation for organic marlstone, moderately good oil shale, and very rich oil shale are given on page 99. Although these rates are plainly subject to rather large errors, as the thickness of the varves is probably not constant within the limits arbitrarily set for each kind of rock, they are probably the right order of magnitude. The time intervals represented by the sections of oil shale measured are given in the table below.

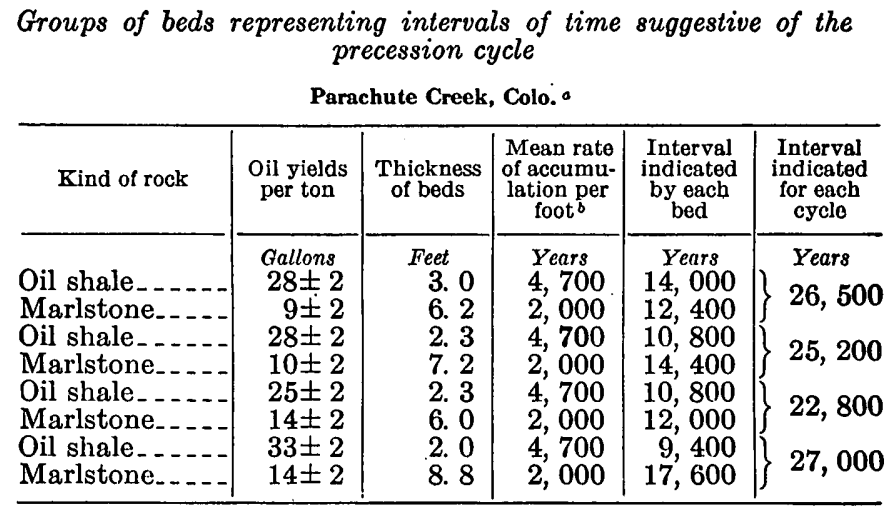

Clear Creek, Colo.

\begin{tabular}{|c|c|c|c|c|c|}
\hline $\begin{array}{l}\text { Marlst } \\
\text { Oil sha }\end{array}$ & $\begin{array}{r}9.8 \\
35.0\end{array}$ & $\begin{array}{r}6.8 \\
.6\end{array}$ & & $\begin{array}{r}13,600 \\
4,900\end{array}$ & \\
\hline Mar & 11. 8 & 6. 9 & & 13,800 & \\
\hline & 22 & & & & 23 \\
\hline & 11. & 3 . & & & \\
\hline & 28 & 1. & & & 16, \\
\hline & 10 & & & 12 , & 25,3 \\
\hline & & & & 13 & $2 b, 3$ \\
\hline & 11 & 4. & & 9 & \\
\hline Oi & 35 & 1. & & 13, & \\
\hline $\mathrm{Oi}$ & $\begin{array}{l}10.6 \\
25.5\end{array}$ & $\begin{array}{l}5 . \\
2 .\end{array}$ & 4,700 & $\begin{array}{l}10,800 \\
10,300\end{array}$ & 21,0 \\
\hline
\end{tabular}

Cathedral Creek, Colo. (upper group) ${ }^{\circ}$

\begin{tabular}{|c|c|c|c|c|c|}
\hline 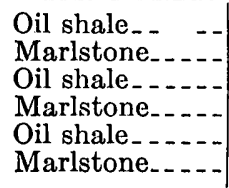 & $\begin{array}{l}25 \pm 5 \\
12 \pm 3 \\
25 \pm 5 \\
12 \pm 3 \\
25 \pm 5 \\
12 \pm 3\end{array}$ & $\begin{array}{l}\text { 1. } 6 \\
6.0 \\
1.4 \\
6.0 \\
1.2 \\
8.0\end{array}$ & $\begin{array}{l}4,700 \\
2,000 \\
4,700 \\
2,000 \\
4,700 \\
2,000\end{array}$ & $\begin{array}{r}7,500 \\
12,000 \\
6,600 \\
12,000 \\
5,600 \\
16,000\end{array}$ & 1,6 \\
\hline
\end{tabular}

Cathedral Creck, Colo. (lower group) $c$

\begin{tabular}{|c|c|c|c|c|c|}
\hline $\begin{array}{l}\text { Oil shale...... } \\
\text { Marlstone... } \\
\text { Oil shale... } \\
\text { Marlstone... } \\
\text { Oil shale._. } \\
\text { Marlstone... }\end{array}$ & $\begin{array}{l}25 \pm 5 \\
12 \pm 3 \\
35 \pm 5 \\
12 \pm 3 \\
35 \pm 5 \\
12 \pm 3\end{array}$ & $\begin{array}{r}1.7 \\
6.5 \\
.8 \\
7.0 \\
.5 \\
6.0\end{array}$ & $\begin{array}{l}4,700 \\
2,000 \\
8,200 \\
2,000 \\
8,200 \\
2,000\end{array}$ & $\begin{array}{r}8,000 \\
13,000 \\
6,500 \\
14,000 \\
4,100 \\
12,000\end{array}$ & 16,100 \\
\hline
\end{tabular}

A verage length of cycle, 21,630 years.

a The oil yields for these beds were supplied by the Columbia Oil Shale \& Refining Co. and are shown as uncertain merely because the samples distilled were collected about a quarter of a mile west of the place where the writer measured his section.

b For marlstone and related rocks yielding less than 15 gallons of oil to the ton the mean rate of accumulation is estimated at 2,000 years to the foot; for moderately good oil shale yielding 15 to 35 gallons, 4,700 years; and for rich oil shale yielding more than 35 gallons, 8,200 years.

c No distillation tests were made for these beds, and the yields indicated here were estimated by the writer. 
Each sedimentary cycle is represented in these partial sections by one bed of oil shale and one bed of organic marlstone, and the average interval indicated is 21,630 years. The length of the precession cycle is between 25,000 and 26,000 years. However, there is a cyclic change in the position of the major axis of the eccentricity of the earth's orbit (revolution of the line of apsides) whose direction of change is opposed to the precession of the equinoxes. Gilbert ${ }^{75}$ stated that "the resultant of the two motions has an average period of about 21,000 years. It is not absolutely regular but ranges ordinarily within 10 per cent of its mean value and exceptionally to 50 per cent above and below." This average figure is suggested by the average interval of 21,630 years for the sedimentary cycles represented by oil shale and organic marlstone as indicated in the table above. The alternation of these two kinds of rocks is what might reasonably be expected to result from the cyclic changes of climate produced by the precession of the equinoxes. If a distinct but yet not abnormally large eccentricity of the earth's orbit is assumed, the precession of the equinoxes should have produced during one half of its cycle a climate in which the summers were short and hot and the winters long and relatively cool and in the other half of the cycle a climate in which the winters were short and mild and the summers long and relatively warm. The mean annual temperature would have remained about the same, however, and the principal differences of climate in the two parts of the cycle would have been in the seasonal distribution of temperature. The greater the eccentricity the more marked would have been these seasonal effects. Spitaler has calculated, according to Brooks, ${ }^{76}$ that at times of maximum eccentricity the seasonal extremes of temperature over continental interiors during onehalf of the precession cycle would be considerably greater than the extremes of temperature at present, when the earth's orbit is more nearly circular, and the seasonal extremes during the other half of the cycle would be correspondingly diminished.

That part of the cycle in which the summers were short and hot and the winters long and relatively cool possibly would have favored the formation of relatively thin beds of rich oil shale. The precipitation of carbonates due to a relatively high temperature of the lake water would have been restricted to one season, and that a short one; accordingly the total thickness of beds formed under these conditions should be less than that of beds formed under conditions that favored precipitation of carbonates throughout a greater part of the year. Yet it is likely that the short hot summers might have been unusually favorable to large production of plankton, which would have given rise to an ooze abnormally rich in organic matter.

\footnotetext{
75 Gilbert, G. K., Sedimentary measurement of Cretaceous time: Jour. Geology, vol. 3 , p. 124,1895 .
}

${ }^{76}$ Brooks, C. E. P., Climate through the ages, pp. 117-119, 1926.
On the other hand, that part of the precession cycle in which the summers were long and warm and the winters short and mild apparently would have provided conditions favoring relatively rapid accumulation of organic marlstone. Under these conditions the temperature of the lake water should have been continually rather high, and this would have favored the precipitation of the carbonates furnished by the streams, whose water was probably somewhat cooler. Thus it seems likely that with a comparable or even smaller production of plankton the rate of accumulation of the ooze during this part of the cycle would have been 'more rapid than during that part with greater seasonal extremes. However, it should be borne in mind that the difference in thickness between the beds of oil shale and those of organic marlstone is doubtless accentuated and perhaps entirely explained by the greater compactibility of the organic material.

The abrupt change from one type of rock to the other in these partial sections of the Green River formation seems to be at variance with the effect that might be expected from the precession of the equinoxes. As the climate probably changes gradually with the precession, the climatic features characteristic of one extreme of the cycle must be transitional into those characteristic of the opposite extreme. And this suggests that such changes in sedimentary rocks as are controlled chiefly by the precession of the equinoxes should be transitional into one another. But the beds of oil shale and organic marlstone are sharply separated from each other. Also, in the Cretaceous rocks of Colorado, where a regular alternation of beds was interpreted by Gilbert ${ }^{77}$ as probably an effect of the precession of the equinoxes, the changes from limestone to shale and the reverse are similarly abrupt. To correlate consistent abrupt changes of lithology like those just cited with the precession cycle it appears to be necessary to postulate that conditions favorable to the formation of one type of sediment, once established, are fairly stable until a certain critical point is reached, when they change rather abruptly to another set of conditions which are equally stable but which favor the formation of a rather different type of sediment. Too little is known of the conditions of sedimentation, however, to venture a guess as to the factors that might govern their stability or be critical for such minor changes in them.

\section{CYCLE OF SALT DEPOSITION}

A third cycle in the beds of the Green River formation is represented by regularly recurrent layers of calcite-filled glauberite (?) cavities. (See pl. 14, B.) These occur in a sample of moderately good oil shale collected by the writer in 1924 at Green River, Wyo., the type locality of the formation. The average interval between the salt layers is 3.4 millimeters, and

7 Gilbert, G. K., op. cit., p. 122. 
the varves in these intervals average 0.065 millimeter in thickness. The period of the cycle is therefore about 50 years. This corresponds to no well-established rhythm, though it suggests remotely the supposed climatic cycle whose average period is about 66 years. It is also interesting, though possibly without significance, to note that according to a graph compiled by Woolley ${ }^{78}$ the two extreme low levels of Great Salt Lake, Utah, occurred about 45 years apart and were separated by a stage at which the level was little more than 15 feet above the lowest level recorded. Similar high stages at approximately the same interval are suggested by the graph for the periods before the first extreme low level and after the second. V. Kremser ${ }^{70}$ found progressive temperature changes in northern Germany that suggest a cycle of about 50 years. Perfiliev, ${ }^{30}$ however, found in the varved sediments of Sakski Lake, in northern Crimea, a clearly defined cycle of about 70 years.

\section{DURATION OF THE EOCENE EPOCH GREEN RIVER EPOCH}

Before discussing the actual estimates of the time interval indicated by the Green River formation it seems worth while to consider how likely it may be that certain sections of this series of lake beds represent essentially continuous deposition. In any lake the position of wave base must, of course, control the rate of sedimentation within the compass of a certain marginal zone, whose width will depend upon the form ratio of the lake. Deposition and erosion must alternate in this zone, but the position of wave base can never control sedimentation over the entire area of a lake bottom. Even though waves reach bottom everywhere and stir up the mud it is inconceivable that more than a small proportion of the material so thrown into suspension could be carried over the lip of an outlet. On the contrary, it must settle again, so that in certain parts, presumably the deepest parts, of even very shallow lakes the sedimentary record must be complete. In deposits formed below wave base there can be no real brealks in sedimentation unless the lake dries up completely.

As the Green River formation consists predominantly of the five types of rock in which varves have been measured, the length of the Green River epoch can be approximated by applying the average rate of accumulation to the total amount of each kind of rock represented in a complete section of the formation. The section measured by the writer along Parachute Creek, in Garfield County, Colo., seems to be the most suitable for this purpose, as it probably furnishes a record of sedimentation in the deepest part of the

\footnotetext{
79 Woolley, R. R., Water powers of the Great Salt Lake Basin: U. S. Geol. Survoy Water-Supply Paper 517, pl. 2, 1924.

10 Frann, Julius, and Süring, R. J., Lehrbuch der Meteorologie, p. 656, Leipzig, 1026.

Bo Perflliov, B. V., T'en years of Soviet science, pp. 402-403, Moscow, 1927.
}

basin, where deposition was nearly if not quite continuous. This section is about 2,600 feet thick and consists of about 7 per cent of fine-grained sandstone, about 76 per cent of marlstone and closely related rocks, about 13 per cent of oil shale that will probably yield between 15 and 35 gallons of oil to the ton, about 4 per cent of oil shale that will yield more than 35 gallons to the ton, and a negligible quantity of algal limestone and oolite. The rates of accumulation already assumed (see p. 99) are as follows: Fine-grained sandstone, 1 foot in 250 years; marlstone and related rocks, 1 foot in 2,000 years; oil shale yielding between 15 and 35 gallons to the ton, 1 foot in 4,700 years; and oil shale yielding more than 35 gallons to the ton, 1 foot in 8,200 years. According to these rates the Green River epoch is estimated to have lasted about $6,500,000$ years. Probably the greatest errors in this estimate lie in assigning the beds to one.or another of the types of varved rocks, whose respective rates of accumulation differ rather widely. The type designated marlstone, for example, though it consists dominantly of rocks closely similar to those containing varves, contains also beds of mudstone and ostracode limestone whose rates of accumulation are unknown but are here assumed to be equal to that of the varved marlstone. With allowance for these and other errors it is perhaps safe to say that the duration of the Green River epoch was between 5,000,000 and $8,000,000$ years. This estimate is based, of course. on the assumption that the paired laminae are actually varves. Further study of the lamination and rhythmic alternations of beds in the vicinity of Parachute. Creek would probably yield a much more accurate estimate.

The same method of estimating the total time required to deposit the Green River formation was applied to two other sections, and these seemed to indicate a much shorter period. One of these sections is a composite section whose basal part was measured on the divide between Douglas and East Salt Creeks, in western Garfield County, Colo., and whose upper part was measured on Cathedral Creek, in sec. 26, T. 3 S., R. 99 W. This section is about 1,800 feet thick and consists of about 15 per cent of sandstone, about 74 per cent of marlstone and related rocks, about 7 per cent of oil shale yielding between 15 and 35 gallons of oil to the ton, about 1 per cent of oil shale yielding more than 35 gallons to the ton, and about 3 per cent of algae reefs. The total time indicated is a little less than 4,000,000 years. The other section is also a composite section whose basal part was measured in Hells Hole Canyon, about in sec. 22, T. 10 S., R. 25 E., Uintah County, Utah, and whose upper part was measured in the canyon of White River, in sec. 27, T. 9 S., R. 25 E., also in Uintah County. This section is about 1,475 feet thick and consists of about 17 per cent of sandstone, about 76 per cent of marlstone, 2.3 
per cent of oil shale yielding between 15 and 35 gallons to the ton, 1.7 per cent of oil shale yielding more than 35 gallons to the ton, and about 2 per cent of algae reefs. The total time indicated by this section is a little less than $3,000,000$ years.

The relatively shorter time indicated by these thinner sections might be accounted for by assuming that in these localities either the varves are thinner or sedimentation was discontinuous. As the rocks are nearly identical wich those occurring at several other localities where the varves have been studied there seems to be little reason to believe that the varves differ appreciably in thickness. But the sandstone in these sections is somewhat coarser, and this feature in itself suggests that scour and deposition may have alternated. Thus it seems a little more likely that these sections are thinner because of interruptions in sedimentation rather than because deposition was slower. The average rate of accumulation for the rocks of the Green River formation as indicated by these three sections is about 1 foot in 2,200 years.

\section{WASATCH, BRIDGER, AND UINTA EPOCHS}

The length of the whole Eocene epoch can be approximated by a method similar to that used for the Green River epoch if it is assumed that there are no significant breaks in sedimentation between the successive formations and if a rate of accumulation for the fluviatile deposits that make up the Wasatch, Bridger, and Uinta formations can be estimated. The assumption of essentially continuous deposition in these basins during Eocene time is well founded, though the evidence involves a general discussion of the stratigraphy of the Eocene formations in the Uinta and Piceance Creek Basins and hardly falls within the scope of this paper. These stratigraphic relations will, however, be treated in another and more comprehensive report. ${ }^{81}$ An estimate of the mean rate of accumulation of the fluviatile deposits of the Wasatch, Bridger, and Uinta formations has a much less definite foundation than that for the Green River formation, yet even a crude estimate yields interesting results.

This rate of accumulation is deduced from figures given by Dole and Stabler ${ }^{82}$ for the average loads of streams and from the inferred relation between the source of material and area of deposition in the Green River Basin of Wyoming. The estimate so obtained is then modified according to the relation between the rate of sedimentation in the ancient Gosiute Lake as computed from Dole and Stabler's data and the rate as indicated by the varves. The computation of the rate of accumulation for the fluviatile deposits is the same as that used on pages 98 and 99 in determining the rate for the lake beds, except that the area of sedi-

${ }^{81}$ Bradley, W. H., The origin and microfossils of the Green River oil shale in Colorado and Utah: U.S. Geol. Survey Prof. Paper - (in preparation).

82 Dole, R. B., and Stabler, Herman, Papers on the conservation of water resources-Denudation: U. S. Geol. Survey Water-Supply Paper 234, p. 84, 1909. mentation is taken as a little less than 17,000 square miles and the area exposed to erosion as a little more than 17,000 square miles, and, in addition, a rolling load of 15 per cent is assumed. Dole and Stabler's data include no estimate of the rolling load. Fortier and Blaney ${ }^{83}$ estimate that about 20 per cent of the total normalload of the Colorado River passing Yuma, Ariz., is bed silt-that is, rolling load. This is probably too high for streams like those in the South Atlantic and eastern Gulf Coast States, and therefore 15 per cent is assumed as a more reasonable estimate. Even this may be too high, yet it seems better to overestimate rather than underestimate this factor, for an error in this direction will result in a more rapid rate of sedimentation and consequently a lower estimate of the length of the Eocene epoch. Further, a rock density of 2.0 is assumed as the average for all the rocks of the Wasatch, Bridger, and Uinta formations. The rock densities of nine specimens of Upper Cretaceous marine shale have recently been determined by P. G. Nutting for W. W. Rubey, both of the United States Geological Survey. These average 1.96. According to data compiled by White ${ }^{84}$ the average rock density of 39 friable sandstones of Mesozoic and Tertiary age is 2.2. Probably these determinations are not strictly applicable to the Eocene fluviatile rocks considered here, yet they serve as a fairly reliable guide. As mudstone predominates in these formations the true average rock density is probably nearer that for shale than that for sandstone. For the purpose in hand, therefore, the assumed rock density of 2.0 appears to be reasonable. On the basis of this assumption and the others stated above the mean rate of accumulation of these rocks appears to be 0.057 millimeter a year. This estimate of the rate is probably too low, but it seems legitimate to apply to it a correction which is determined by the discrepancy between the probable annual increment of sediment supplied to Gosiute Lake as computed from Dole and Stabler's data ${ }^{85}$ and the annual increment as indicated by the varves. (See p. 98.) The varves in the Green River formation indicate a mean rate of accumulation of 1 foot of rock in about 2,200 years, and this is nearly twice the rate indicated by the calculation on page 98 from Dole and Stabler's figures. Hence, if approximately this same relation is assumed to apply to the rate of accumulation of the Eocene fluviatile deposits, then it appears reasonable to double the calculated rate of 0.057 millimeter a year. Accordingly, 0.1 millimeter a year is taken as an approximation to the rate for the accumulation of the fluviatile rocks in the Uinta and Piceance Creek Basins. This is equivalent to 1 foot in about 3,000 years.

${ }^{83}$ Fortier, Samuel, and Blaney, H. F., Silt in the Colorado River and its relation to irrigation: U. S. Dept. Agr. Tech. Bull. 67, p. 53, 1928.

84 White, David, Gravity observations from the standpoint of the local geology: Geol. Soc. America Bull., vol. 35, pp. 214-215, 1923.

${ }_{85}$ Dole, R. B., and Stabler, Herman, op. cit., pp. 78-93. 
The possible significance of the discrepancy between the rate of accumulation calculated from Dole and Stabler's data and the rate indicated by the varves may appropriately be pointed out here. As the rate indicated by the varves is the more rapid, it seems to imply either that the area being eroded was larger than that assumed for these calculations or that the rate of erosion was more rapid than in the streams of the South Atlantic and eastern Gulf Coast States, which were chosen as corresponding to the streams feeding Gosiute Lake. Of these two explanations the second seems the more likely, for a large part of each of these ancient streams was in the mountains flanking the basin and therefore probably had a steeper average gradient than the rivers of the southeastern United States. If the rainfall of the Gosiute Lake Basin during Eocene time was distinctly seasonal, that, too, would have favored more rapid erosion.

At first thought it may perhaps seem somewhat surprising that the rate of sedimentation in Gosiute Lake should have exceeded the rate of accumulation of the Eocene fluviatile deposits, especially as the fluviatile deposits are generally somewhat coarser grained. But this relation appears to be reasonable in view of the fact that the lake provided a very efficient settling basin, which retained practically all the material brought by streams, either in suspension or as rolled load. It also retained even the finest clay particles and apparently much of the dissolved mineral matter. Moreover, the lake bottom-that is, the area receiving sediments-was somewhat smaller for essentially the same drainage basin than the area of deposition during the fluviatile epochs. Then, too, sedimentation in the lake was more nearly uniform and continuous over all parts of the lake bottom, whereas the fluviatile deposition, as usual, was plainly more erratic. Streams deposit material relatively rapidly but locally. and, in general, not continuously. Long intervals are likely to occur between successive increments of material at any particular place. Furthermore, slight changes in the conditions of the stream may bring about alternate erosion and deposition. Fluviatile sedimentation also is less efficient than lacustrine sedimentation. In perennial streams much of the finest suspended material and a large proportion of the dissolved mineral matter is carried far from its source. In arid regions with interior drainage the streams must, of course, deposit their entire loads. However, it is unlikely that the fluviatile deposits of the Wasatch, Bridger, and Uinta formations were formed in basins with interior drainage. From these considerations the writer concludes that if varves are found in these rocks of fluviatile origin they may be considerably thicker than those in the lake beds, yet the actual rate of accumulation of the fluviatile formation over a long period of time $61455^{\circ}-30-8$ probably was distinctly less rapid. It is possible that a relatively slow rate of accumulation for fluviatile deposits may be more general than is commonly supposed.

According to the estimates given above, 1 foot in 3,000 years is assumed to represent the mean rate of sedimentation of all the Eocene formations of fluviatile origin of the Uinta and Piceance Creek Basins. Measurements by Gale, ${ }^{86}$ Spieker and Reeside, ${ }^{87}$ and the writer indicate that the average thickness of the Wasatch formation is about 3,600 feet. At the assumed rate of accumulation this would indicate a time interval of nearly $11,000,000$ years. Osborn ${ }^{88}$ gives the thickness of what the writer regards as the Bridger formation $^{89}$ in the Uinta Basin, Utah, as about 1,300 feet and that of the Uinta formation as about 600 feet. These indicate a time interval of nearly $4,000,000$ years for the Bridger and nearly 2,000,000 years for the Uinta. In the subjoined summary of the Eocene epoch a factor of uncertainty of about 50 per cent is applied to estimates for these formations consisting of fluviatile deposits.

\section{SUMMARY OF ESTIMATES}

From the foregoing calculations based upon measurements of some of the beds of the different formations the length of the Eocene epoch may be estimated as follows:

Estimate of the length of the Eocene epoch

\begin{tabular}{|c|c|c|c|}
\hline \multirow{2}{*}{ Formation } & \multicolumn{3}{|c|}{ Time interval (million years) } \\
\hline & Minimum & Calculated & Maximum \\
\hline $\begin{array}{l}\text { Wasatch } \\
\text { Green River } \\
\text { Bridger and Uinta. }\end{array}$ & $\begin{array}{l}5.25 \\
5 \\
2.75\end{array}$ & $\begin{aligned} \text { 10. } 7 \\
6.5 \\
5.7\end{aligned}$ & $\begin{array}{l}\text { 16. } 25 \\
8 \\
8.50\end{array}$ \\
\hline $\begin{array}{l}\text { Barrell's estimate of the Eocene } \\
\text { epoch based on radioactive } \\
\text { minerals. }\end{array}$ & $\begin{array}{l}13 \\
20\end{array}$ & $\begin{array}{r}22.9 \\
23 \text { (mean) }\end{array}$ & 32. 75 \\
\hline
\end{tabular}

It is interesting to compare this estimate with those based upon the lead-uranium ratios of radioactive minerals. Holmes ${ }^{90}$ gives an age determination based upon a specimen of pitchblende from Gilpin County, Colo., which is late Cretaceous or early Eocene and whose calculated age is about $60,000,000$ years. Barrell ${ }^{91}$ based his estimates of the early Tertiary epochs upon the age determination of a radioactive

${ }^{80}$ Gale, H. S., Coal fields of northwestern Colorado and northeastern Utah: U. S. Geol. Survey Bull. 415, p. 82, 1910.

${ }^{87}$ Spieker, E. M., and Reeside, J. B., jr., Cretaceous and Tertiary formations of the Wasatch Plateau, Utah: Geol. Soc. America Bull., vol. 36, p. 440, 1925.

s8 Osborn, H. F., The titanotheres of ancient Wyoming, Dakota, and Nebraska: U. S. Geol. Survey Mon. 55, p. 96, 1929.

${ }_{89}$ Osborn refers to these beds in ascending order as Uinta A, Uinta B 1, and Uinta B 2; what the writer has called here the Uinta formation he calls the true Uinta or Uinta $C$.

Holmes, Arthur, The age of the earth, p. 73, 1927.

"Barrell, Joseph, Rhythms and the measurements of geologic time: Geol. Soc. America Bull., vol.8, pp. 875-876, 884, 1917. 
mineral from Ireland, which is of lower Oligocene or upper Eocene age and whose calculated age is about $31,000,000$ years. With this as a tie point he estimated the relative lengths of the epochs on the basis of stratigraphic evidence and concluded that the length of the Eocene was between about $20,000,000$ and $26,000,000$ years. The very close correspondence between the average of the writer's estimates, a little less than
$23,000,000$ years, and the average of Barrell's estimates, $23,000,000$ years, is doubtless merely a coincidence, for the evident errors in the writer's method of estimating are certainly of the order of several million years. Nevertheless, as the writer's estimate is wholly independent of those based on radioactive minerals it seems to provide an interesting though an obviously rough check. 